\title{
Wage response to global production links: evidence for workers from 28 European countries (2005-2014)
}

\author{
Aleksandra Parteka ${ }^{1}$ ( ) Joanna Wolszczak-Derlacz ${ }^{1}$ (1)
}

Published online: 23 May 2020

(c) The Author(s) 2020

\begin{abstract}
Using rich individual level data on workers from 28 European countries, this study provides the first so extensive cross-country assessment of wage response to global production links within GVC in the period 2005-2014. Unlike the other studies, the authors (i) address the importance of backward linkages in globally integrated production structures (capturing imports of goods and services needed in any stage of the production of the final product); (ii) measure occupational task profile of workers with country-specific indices of routinisation; (iii) compare the impact of global production links on wages between workers from Western, Central-Eastern and Southern Europe; employed in manufacturing and non-manufacturing sectors; (iv) account for direct and indirect dependence on GVC imports from developing and high income countries. The study takes into account the potential endogeneity issues. The results suggest that global import intensity of production exhibits negative pressure on wages in Europe. This effect concerns mainly workers from Western Europe employed in manufacturing and is driven by production links with non-high income countries but our counterfactual estimates suggest that the effect is economically small.
\end{abstract}

Keywords Wages - Global value chains - Global import intensity of production · Tasks $\cdot$ EU

JEL Classification F14 $\cdot$ F16 $\cdot$ J31

\begin{abstract}
The research has been conducted within the project financed by the National Science Centre, Poland (Narodowe Centrum Nauki, NCN)_ grant number UMO-2015/19/B/HS4/02884. Sabina Szymczak provided excellent research assistance. Also, we would like to thank Piotr Lewandowski (IBS Warsaw) for his help concerning task content measurement, the participants to numerous conferences and workshops for valuable comments and the anonymous referees whose remarks helped us to improve the paper.
\end{abstract}

Electronic supplementary material The online version of this article (https://doi.org/10.1007/s1029 0-020-00380-4) contains supplementary material, which is available to authorized users.

Aleksandra Parteka aparteka@zie.pg.gda.pl

Extended author information available on the last page of the article 


\section{Introduction}

The labour market effects of production relocation are still being debated. Offshoring, understood as 'the process of changing the geographic assignment of the mix of tasks needed to produce a single final good or service' (Hummels et al. 2018: 983) has traditionally been seen as a threat to domestic workers (job losses, declining wages, heightened inequality). The topic has become a media phenomenon, an issue in the political debate and one of the main themes in current economic literature. The theoretical literature on the distributional consequences of offshoring and global value chains (GVCs), recently reviewed by Frassen (2019), is abundant but ambiguous, particularly when it comes to predicting the combined effect of the various, often conflicting mechanisms at play. ${ }^{1}$ In the empirical literature as well, despite the impressive development of measurements and methods the debate on the labour market consequences of importing foreign inputs is still unresolved, due to the gap between concepts and what can be feasibly demonstrated given the data (Hummels et al. 2018).

This paper uses rich individual-level data on workers in 28 European countries in the period from 2005 to 2014 to produce a multidimensional cross-country evaluation of the factors that determine wages in labour markets characterised by strong links to GVCs and task-related specificity of jobs. The core of our empirical analysis relates to the way we quantify dependence on foreign inputs and the role of cross-border production relations in generating labour market outcomes. The standard measures of fragmentation are based on the ratio of imported intermediates in a given industry to its output or value added (Feenstra and Hanson 1999). That is, the focus is on the last stage of production only, as if the use of foreign inputs were independent from the previous stages (whether performed domestically or abroad). Instead we employ the latest release of the WIOD input-output data ${ }^{2}$ and methodology proposed by Timmer et al. (2016), proxying fragmentation by a newly devised index of global import intensity of production (GII), which counts imports of goods and services required in any stage of production, including trade with third countries. ${ }^{3}$ GII measures the extent to which a given industry depends on imported intermediates to attain its total production value (direct exposure) and previous international and cross-industry links (indirect exposure). Our approach is thus closer to the framework of sequential production and national interdependence driven by vertical specialisation and GVCs (Antràs and Chor 2013; Kohler 2004; Costinot et al. 2013) than to the 'classic' offshoring literature, which considers the last tier only (see Hummels et al. 2018, Sect. 2 for a review).

\footnotetext{
1 For instance, see Franssen (2019: 3, Table 1) for a summary of conflicting theoretical predictions of the effects of GVCs on the relative demand for skilled labour present in the alternative models. In their review, Hummels et al. (2018: 1021) observe that 'the effects for workers depend on the model at hand'.

${ }^{2}$ World Input Output Database, November 2016 release (see Timmer et al. 2015 for details). See Feenstra (2017) for a discussion of the classic measures of offshoring and 'second-generation statistics' on fragmentation based on input-output data.

3 The R code to compute GII (Szymczak et al. 2019) is available-see Sect. 3.1.
} 
To illustrate this point, we refer to the statistics on GVC involvement (Table 1). Between 2000 and 2014 the import intensity of European production (ratio to total output) increased from $15.9 \%$ to $20.2 \%$. $^{4}$ According to the monetary interpretation of GII proposed by Timmer et al. (2016), this means that in 2014 one dollar of goods and services finished in Europe generated about 20 cents worth of imports worldwide. Conventionally measured offshoring-the inputs used in the last stage of production-accounts for a bit less than half the increase that occurred over this period. The rest of the imported intermediates were used in earlier tiers and can be traced back in the GVC framework. The United States is less dependent on imported intermediates, but there was an increase in GII there as well (from $7.9 \%$ in 2000 to $8.8 \%$ in 2014). Worldwide, the ratio of GVC imports (i.e. imports by the country where the last stage of production occurred and by all other countries involved in earlier stages of production) to the output of the final products was approximately $16 \%$ in $2014\left(12 \%\right.$ in 2000). ${ }^{5}$ And only a third of it can be ascribed to the final stage of production, so proper measurement of dependence on foreign inputs in earlier stages is essential. To date, however, the literature on the labour market effects of production fragmentation has neglected this aspect.

The studies of the effects of fragmentation on the European labour market that have considered the task content of jobs suffer another severe limitation, namely limited coverage: these inquiries have involved only a few Western European countries, ${ }^{6}$ not the other, less highly developed economies of Southern or Central and Eastern Europe (CEECs). ${ }^{7}$ Furthermore, often only the impact on manufacturing workers is analysed (as in Geishecker et al. 2010; Baumgarten et al. 2013; Hummels et al. 2014; Geishecker and Görg 2013). ${ }^{8}$ The dependence on foreign production is sector-specific and non-negligible in non-manufacturing activities (Geishecker and Görg 2013), ${ }^{9}$ so we do not limit our study to manufacturing alone.

\footnotetext{
${ }^{4}$ Based on the GII index computed with WIOD data (release 2016). See Sect. 3.1 for details.

5 These values differ from those of Timmer et al. (2016) because of the different level at which the measurement is made and because of the weighting scheme adopted. Our unweighted averages for the 'World' are much closer to the values reported by Timmer et al. (2016: 33).

${ }^{6}$ Empirical evidence has been compiled for: Germany (Baumgarten 2015; Baumgarten et al. 2013; Becker et al. 2013; Becker and Muendler 2015), Denmark (Hummels et al. 2014), the United Kingdom (Geishecker and Görg 2013), or these three countries together (Geishecker et al. 2010).

7 So far, analysis of the labour market impact of trade or offshoring in relation to the CEECs markets has been from the perspective of the potential threat to Western European workers (Abraham and Konings 1999; Geishecker 2006; Dauth et al. 2014) or the effects observed within the CEECs (Egger and Egger 2002). The task literature has shown that in most CEECs countries, unlike Western European economies, in intensity of routine cognitive tasks grew (Hardy et al. 2018).

8 Additionally, Baumgarten (2015) studied the impact of material and business offshoring on occupational instability among German workers. Becker et al. (2013) considered workers in German manufacturing and service sectors. Other studies on offshoring in non-manufacturing sectors include Amiti et al. (2005), Crino (2010), and Geishecker and Görg (2013).

9 Timmer et al. (2016, p.25-26) detected appreciable variation in the intensity of foreign inputs in goods production and service production: many services are obviously produced locally (e.g. public services, education, recreation), but construction, for instance, is just as heavily dependent on foreign inputs as some manufacturing industries. Johnson and Noguera (2017) documented that over time (1970-2009), the ratio of value added to gross exports decreased in manufacturing (by 20 p.p.) but increased in agriculture and services.
} 
Table 1 Global import intensity of production, as \% of final output (World, Europe, USA). Source Own calculations based on WIOD (release Nov 2016) and Timmer et al. (2016) methodology

\begin{tabular}{llllllll}
\hline & \multicolumn{3}{l}{ Last stage of production } & & \multicolumn{3}{c}{ All tiers of production $(G I I)$} \\
\cline { 2 - 3 } & World & Europe (28) & USA & & World & Europe (28) & USA \\
\hline 2000 & 5.2 & 7.4 & 2.8 & & 11.8 & 15.9 & 7.9 \\
2014 & 6.3 & 8.8 & 3.5 & & 15.8 & 20.2 & 8.8 \\
\hline
\end{tabular}

Average values calculated across countries and 56 industries and weighted by industrial value added $\left(V A_{i j t}\right)$. GII calculated as in Eq. 1, GII reflects the ratio of GVC imports to the output of the final products and ranges here between 0 and $100 \%$. Europe (28) consists of: $W$-Western Europe (AT, BE, CH, DE, DK, FI, FR, IE, IT, NL, NO, SE, UK); $S$-Southern Europe (CY, ES, EL, PT); $C E E$ - Central and Eastern Europe (BG, CZ, EE, HU, LT, LU, LV, PL, RO, SI, SK)

Our central question is thus: are wages in Europe affected by globally measured dependence on foreign inputs, including direct and indirect exposure, given all the other dimensions of the wage determination process $?^{10}$ To answer, we construct a rich dataset: individual-level information on wages, occupational task profiles, personal and job characteristics on 1.3 million workers in 28 European countries over the period 2005-2014. We match our microdata with input-output measures of sectoral dependence on foreign inputs, other sector characteristics, and information on national labour market institutions and wage bargaining schemes. In addition to considering all the pre-final tiers of production, we compare the effects of dependence on foreign inputs measured globally, regardless of country of origin, with the effects of dependence on inputs from less developed countries only. Further, given our cross-country approach, we consider the task profiles of workers, which are occupation- and country-specific (Lewandowski et al. 2019).

The paper is structured as follows. Section 2 briefly describes the theoretical background and some essential contributions on production fragmentation and wages in Europe, which our paper expands on. Section 3 presents the data and methodology and the measurement of global dependence on foreign inputs and of wages in Europe. The empirical strategy and the results of the estimations for various subsamples are presented in Sect. 4. The last section concludes. Numerous robustness checks are included in the additional material and available in the online appendix.

\footnotetext{
10 Dealing with many countries in the analysis, we limit the study to the effects on wages, treating the employment and labour demand effects of fragmentation as issues requiring separate inquiry. See Ebenstein et al. (2014) for a joint micro-level analysis of the impact of production fragmentation on wages and employment shifts in the U.S.
} 


\section{The literature}

\subsection{Theoretical background}

On the theoretical plane our paper is at the crossroads between the literature on the effects of offshoring on domestic workers and that on sequential production, which can be adopted to GVC analysis. ${ }^{11}$ As recently described by Franssen (2019), the theoretical literature on the distributional effects of GVC is abundant but ambiguous, and 'the hypothesized effects are highly dependent on the microeconomic foundations of the model chosen' (Feenstra 2010, p. 3).

The conceptualisation of offshoring through trade-in-tasks has become a widely accepted reference point in the literature on production fragmentation. Theoretical models have addressed the ambiguity of the effects on domestic labour by studying how the overall outcome (wage loss or wage gain, say) is generated by the interplay of the contrasting forces in play in offshoring. According to Grossman and RossiHansberg (2008), the wage impact of the growing dependence on foreign inputs due to falling offshoring costs operates indirectly through three main channels: the influence on relative productivity, the price effect and the labour supply effect. ${ }^{12}$ Paradoxically, if the productivity gains from production relocation are sufficiently large, when tasks are offshored the ultimate result may actually be a wage gain that includes workers performing less demanding tasks. ${ }^{13}$ However, other models suggest that offshoring may engender wage decline because of the pressure on domestic workers to accept lower wages for fear of job offshoring (Jeon and Kwon 2019) or the reallocation of workers from high- to low-productivity firms, with lower wages (Egger et al. 2015). A whole range of wage effects is possible, depending on the global engagement of firms (Amiti and Davis 2011): a decrease in output tariffs lowers wages in import-competing firms and raises them in exporting firms; a decrease in input tariffs, by contrast, will raise wages at import-using firms relative to those paid by firms that rely on local inputs.

\footnotetext{
${ }^{11}$ GVCs and value-added trade have been described, among others, by Antràs and Chor (2013), Costinot et al. (2013), Johnson and Noguera (2012, 2017), Koopman et al. (2014), Los et al. (2015a, b), Timmer et al. (2015, 2016), Baldwin and Lopez-Gonzalez (2015). Some of the papers (e.g. Amador and Cabral 2015) have referred to GVCs but, in reality, they describe labour market effects of offshoring.

${ }^{12}$ In short, the final effect is the resultant of these three mechanisms. Tasks vary in their offshoring cost and low-skilled tasks can be offshored. The relative-price effect occurs when a fall in offshoring costs changes a large country's terms of trade. Price movements are mirrored by movements in relative costs, which typically exerts downward pressure on low-skill wage via the Stolper and Samuelson mechanism. The labour-supply effect derives from the reabsorption of the workers who used to do the offshored tasks: this may (but also may not) contribute to a decline in their wages. Finally, the productivity effect that Grossman and Rossi-Hansberg (2008) predict may seem counterintuitive, in that it implies that workers whose jobs are being relocated may actually benefit from a decrease in offshoring costs: the resulting cost savings for firms increases productivity, which in turn boosts firms' demand for low-skilled labour and pushes their wages up.

${ }^{13}$ The possibility that wages might rise as a result of relocation was predicted earlier by Markusen (1989) in his model of trade in differentiated intermediate inputs: upstream production stages can be complementary to downstream tasks, resulting in higher wages from value added trade in the industry.
} 
Models of sequential, multistage production and the theories of interdependence driven by vertical specialisation (Costinot et al. 2012, 2013; Antràs and Chor 2013; Kohler 2004) have also produced ambiguous theoretical predictions on how the production chain will affect factor prices (including, especially, wages). But they also confirm that in a world of globally integrated production, the outcomes (wages, say) observed at any one stage (e.g. final) should not be analysed separately from what happens at the previous stages. Kohler (2004) argued that the ambiguity of the response of wages to production fragmentation is deepened by cross-industry links in a multistage production setting. Costinot et al. (2013) developed a simple theory of trade with sequential production to show how global supply chains affect international interdependence and Costinot et al. (2012) provide a multifactor version to study the implications for wage inequality. In such a model, with sequential production, wages respond to changes in the prices of the intermediate goods used in the industry. Hence, efficiency gains thanks to cheaper foreign inputs upstream can affect downstream productivity indirectly, and with it the wages of the workers. This is the perspective that motivates our empirical approach: earlier production tiers, performed offshore, can affect the wages of workers employed domestically in the later stages of GVC, closer to final demand.

\subsection{Production fragmentation, GVC, and wages in Europe-the empirical evidence}

The recent empirical literature on the fragmentation-wage nexus generally follows the influential theoretical models of trade-in-tasks (Grossman and Rossi-Hansberg 2008, 2012; Baldwin and Robert-Nicoud 2014). This literature consists of several different strands: the sets of studies using respectively industry-level data, firm-level data, worker-level data, and matched worker-firm data (see Hummels et al. 2018 for an excellent review). The crude division of workers into skilled and unskilled in a cross-section of industries that marked the first wave of studies on the labour market consequences of production fragmentation for different workers is no longer sufficient. In particular, tasks clearly differ from skills, especially when the objective is to gauge the potential offshorability of certain occupations (Blinder 2006; Blinder and Krueger 2013). ${ }^{14}$ Consequently, to evaluate the consequences of globalisation for heterogeneous groups of workers, empirical research on international trade has adopted the task setting, originally developed to analyse variation in skill requirements within occupations and the changing task composition of labour markets owing to technological progress (among others: Spitz-Oener 2006; Autor et al. 2003; Acemoglu and Autor 2011; Autor and Handel 2013).

Much of the task-based work on the labour market implications of production fragmentation (offshoring) refers to the United States (Acemoglu and Autor 2011; Ebenstein et al. 2014; Autor et al. 2014). And a good share of this literature focuses

\footnotetext{
14 Baumgarten et al. (2013), in their assessment of the cross-industry effects of offshoring on wages in German manufacturing, demonstrated the substantial heterogeneity between skills and tasks.
} 
on the so-called 'China syndrome' or 'China shock' (among others: Autor et al. 2014; Shen and Silva 2018; Feenstra and Sasahara 2018). ${ }^{15}$

Not many papers are closely related to our research, with its focus on Europe, microdata and task-profile (we exclude the literature using industry-level data, such as Polgár and Wörz 2010; Parteka and Wolszczak-Derlacz 2015; Wolszczak-Derlacz and Parteka 2018). The more detailed evidence, which considers the heterogeneity of workers in terms of individual characteristics, is strongly dependent on the availability of microdata, which is why just a handful of countries (and principally Germany) have dominated the debate.

Of the European countries, Germany is by far the most intensively studied. Becker and Muendler (2015) documented significant trade-task changes in the German economy over three decades (1979-2006): imports of intermediates grew, and the German workforce increasingly specialised in non-offshorable activities Baumgarten et al. (2013). demonstrated an adverse effect of offshoring on wages, depending on the task profile of the occupations involved (higher non-routine content effectively protects workers from the wage repercussions of production relocation). Becker et al. (2013) used plant level data for German multinationals to examine the relationship between offshoring and the composition of skills and tasks in Germany. Their results suggested positive relationships between offshore employment and the shares of non-routine and interactive tasks in the total wage bill. But they also found that in any case the economic impact of offshoring on the composition of the labour force is modest and concluded that much of the variation in wage shares is explained by other factors.

The evidence on other countries confirms that offshoring has uneven effects on workers, depending on skill/task type. Hummels et al. (2014), on matched workerfirm data from Denmark, demonstrated that offshoring increases the wages of the skilled and decreases those of the low-skilled. However, considering that skills do not overlap perfectly with tasks, the wage effects vary according to tasks (that is, workers performing routine tasks suffer the most). Geishecker and Görg (2013) merged industry-level data on offshoring for the United Kingdom with individuallevel data on wages (their setting thus resembles ours) and showed that the offshoring of services affects the wages of low- and medium-skilled workers negatively and leads to a wider earnings gap between skilled and unskilled. Finally, Geishecker et al. (2010), combined data for Germany, the United Kingdom, and Denmark to determine whether differences in labour market institutions may have produced differences in the wage impact of outsourcing. Surprisingly, they found that the estimated effects are actually quite similar across the three countries and fairly small.

\footnotetext{
15 Typically, these studies postulate job loss due to imports from China. However, an interesting later work (Feenstra and Sasahara 2018), using the same WIOD input-output data we use here, discusses the job impact of U.S. exports as well as imports. Using the demand-side methodology of Los et al. (2015b), they quantify the positive effect of U.S. exports on employment. Their combined analysis shows that the expansion in U.S. merchandise exports relative to imports from China between 1995 and 2011 generated net demand for about 1.7 million jobs. Comparing the growth of U.S. merchandise exports to total merchandise imports, one finds a fall in net labour demand; but comparing total U.S. exports and imports, one finds an increase in net labour demand, thanks to the growth in service exports.
} 
In our study we also check whether the impact of GII on wages in Europe depends on the source of the imported inputs. The literature has confirmed that the provenance of inputs is indeed critical. Becker et al. (2013) showed that offshoring by German multinationals to low-income countries (except Central and Eastern Europe) produces a stronger employment response in Germany. Wolszczak-Derlacz and Parteka (2018) examined a 40-country worldwide sample. Using industry-level wage data and breaking the input-output offshoring measure down according to source country, they found a negative (but small) wage impact of offshoring to lowwage countries. $^{16}$

As far as task evaluation is concerned, to date most task-based labour market studies have focused on a single country for which the classification of tasks is available: the U.S. (Autor and Handel 2013; Autor et al. 2014; Ebenstein et al. 2014) or Germany (Baumgarten 2015; Becker et al. 2013). Alternatively, they simply assume that the task profile of workers in the countries they want to analyse is the same as in the United States (based on O*NET data), which Lewandowski et al. (2019) have shown to be a considerable simplification. For works along these lines, see Goos et al. (2014), Arias et al. (2014), Lewandowski et al. (2017), and Hardy et al. (2018), applying O*NET to LFS data in the European Union and/or OECD countries; or the World Development Report (2016), which utilises the typology of occupations developed by Autor (2014), based on U.S. data, to analyse changes in employment shares in developing countries.

Few studies have explicitly addressed the GVC-wage nexus merging industrylevel data on GVC with individual data on workers' wages. Shen and Silva (2018) studied the relationship between the value added of exports from China and wages in the United States, demonstrating that the effects depend on the position of the Chinese industry in the GVC (its degree of downstreamness). Similarly, Szymczak et al. (2019) use the CEECs sample to show how the position of industries in the production chain affects wages. Parteka and Wolszczak-Derlacz (2019), constructing a cross-sectional dataset on nine European countries and the United States, is the work most resembling the present paper in terms of data and methodology. Those results suggested that growing cross-border industrial interdependence (measured as the foreign share in the industry's value added) decreases the wages of some workers, namely those who perform more routine tasks and are less well educated. But effects detected empirically are quite modest. In any event, that study did not cover the entire European labour market; it used a fairly crude classification of workers by task content of jobs; and it failed to explore the role of backward production linkages in multistage GVCs. The subsequent analysis addresses these shortcomings.

\footnotetext{
16 Importantly, the classification of low-wage countries is not based on aggregate data but on relative wage levels and varies across industries and time (available at https://static-content.springer.com/esm/ art\%3A10.1007\%2Fs10663-016-9352-4/MediaObjects/10663_2016_9352_MOESM1_ESM.xlsx).
} 


\section{Empirical setting}

In our study we consider workers from 28 European countries including Western Europe-W (AT, BE, CH, DE, DK, FI, FR, IE, IT, NL, NO, SE, UK); Southern Europe-S (CY, ES, EL, PT) and Central and Eastern Europe-CEECs (BG, CZ, EE, HU, LT, LU, LV, PL, RO, SI, SK). We match micro-level information (from EU-SILC) with sector-level statistics on countries' dependence on foreign inputs based on WIOD (release November 2016), described below.

\subsection{The measurement of GII}

In order to measure countries' and industries' global dependence on imported inputs we draw on Timmer et al. (2016) new accounting framework which they use to explain the global trade slowdown. ${ }^{17}$ Following them, we employ the newest available release of industry-level data from WIOD (November 2016) and use global import intensity of production' $(G I I)$ index. ${ }^{18} G I I$ is a backward measure which takes into account 'the imports by the country in which the last stage of production takes place, as well as imports by other countries that are involved in earlier stages of production. Moreover, it includes imports of intermediate goods as well as intermediate services (such as supporting business services).' (Timmer et al. 2016, p.4). It thus noticeably differs from offshoring intensity measured (in the spirit of Feenstra and Hanson 1999) at one stage of production only as a ratio of imported inputs to the industrial output value. GII measures all imports of intermediates by all countries in the value chain induced by a dollar of output of a final product. Consequently, its interpretation in terms of total contribution of foreign inputs into the domestic production is also straightforward-contrary to the measures based on export decomposition (vertical specialisation, VS — domestic value added in exports: Hummels et al. 2001; Koopman et al. 2014 or the VAX ratio-value added exports: Johnson and Noguera 2012). ${ }^{19}$

We adopt a sequential approach to measure the dependence on foreign inputs, in other words we use the information on imported inputs employed in the last stage of production and on imported inputs employed in all the previous production stages (backward movement along the GVC). Formally, GII is computed as follows

\footnotetext{
17 In particular, they argue that before the economic crisis the import intensity was increasing due to high demand for durables and to increasing international production fragmentation while after 2011 the fragmentation growth halted and the demand shifted to services.

18 The R code to compute GII (Szymczak et al. 2019) is available at: https://ezarzadzanie.zie.pg.gda.pl/apps/WorkingPapers/WP_GUTFME_A_53_code_accompanyingWP5 3_GII_56ind.R.

19 The recent empirical evidence on long-run trends (four decades: 1970-2009) in value added exports is provided by Johnson and Noguera (2017) while Baldwin and Lopez-Gonzalez (2015) present an overview of supply-chain trade developments since 1995 (from the perspective of: importing to produce; importing to export and value-added trade).
} 
(Timmer et al. 2016, p. 10-12). ${ }^{20}$ Let $a(t, j)(u, k)$ be the value of inputs from industry $t$ in country $j$ required by industry $u$ in country $k$ to produce one dollar of its gross output. Good $z$ is finalised in $(s, i)$. All imports needed in each stage (tier) of production of $\operatorname{good} z$ are defined as:

$$
\begin{gathered}
h_{z}^{\text {tier } 0}=\sum_{u} \sum_{k \neq i} a(u, k)(s, i) \\
h_{z}^{\text {tier } 1}=\sum_{t} \sum_{j \neq k} \sum_{u} \sum_{k}[a(t, j)(u, k)][a(u, k)(s, i)]
\end{gathered}
$$

$h_{z}^{\text {tier } 2}=\ldots$ and so on, so the GII of $z$ is equal to:

$$
G I I=h_{z}=h_{z}^{\text {tier } 0}+h_{z}^{\text {tier } 1}+h_{z}^{\text {tier } 2}+\ldots=\sum_{t} \sum_{j \neq k} \widehat{a}_{z}(t, j)(u, k)
$$

where $\hat{a}_{z}(t, j)(u, k)$ is the delivery of inputs from $(t, j)$ to $(u, k)$ induces by the production of good $z$.

The production of intermediate inputs provided by the first-tier suppliers involves intermediates from second-tier suppliers and so on, summing up to all tiers of production given by GII. GII takes the values between 0 and 1 where zero means that finalizing country does not need to import intermediates in any stage of production of product $z$ while the value of 1 indicates a complete dependence on foreign inputs along the value chain. ${ }^{21}$

Figure 1 shows average values of GII in our sample of 28 European countries in 2014 (being the last year of input-output data in WIOD, as well as the last year of our analysis; values are weighted by the industry value added). GII (expressed as an index $0-1$,where the value of 1 corresponds to a total, $100 \%$ dependence of the final production on imported inputs, calculated along all the backward stages of production) range between $13 \%$ of final output in Greece to $55 \%$ in Luxembourg. European countries are generally more dependent on foreign inputs than big economies like US or China, where GII equals to (respectively) 0.08 and 0.13 (8 and 13\%). In almost all of the countries less than half of GII is driven by imports by the country in which the last stage of production took place (in black), while the other half depends on inputs imported in earlier stages of production which involve third-country trade. It means that conventionally measured offshoring (which accounts for imported intermediates

\footnotetext{
20 The notation and description of GII in this section comes from the presentation of M. Timmer at HKUST Conference on International Economics, Hong Kong, June 1-2, 2017.

21 Empirically (using input-output tables and following Leontief), gross output related to the production of final good $z$ is derived as: $=\mathbf{Y}_{\mathbf{z}}=(\mathbf{I}-\mathbf{A})^{-1}[\mathbf{z}]$, where $\mathbf{A}$ is the matrix of intermediate input coefficients (foreign and domestic) while $\mathbf{I}$ is the identity matrix. Intermediate inputs linked to the production of good $\mathrm{z}$ are then given by $\widehat{\mathbf{A}_{\mathbf{z}}}=\mathbf{A} \operatorname{diag}\left[\mathbf{Y}_{\mathbf{z}}\right]$. All intermediate imports related to $z$ are given by: $h_{z}=\mathbf{u}^{\prime}\left(\mathbf{T} \circ \widehat{\mathbf{A}_{\mathbf{z}}}\right) \mathbf{u}$ where $\mathbf{T}$ is an indicator matrix (with zero's for domestic flows and $\mathbf{u}$ being a summation vector). Theoretically, GII can be bigger than 1 when imports are measured on a gross basis and double counting of value added contributions takes place-see (Timmer et al. 2016: 11; Koopman et al. 2014) but we exclude such (few) observations from the sample.
} 


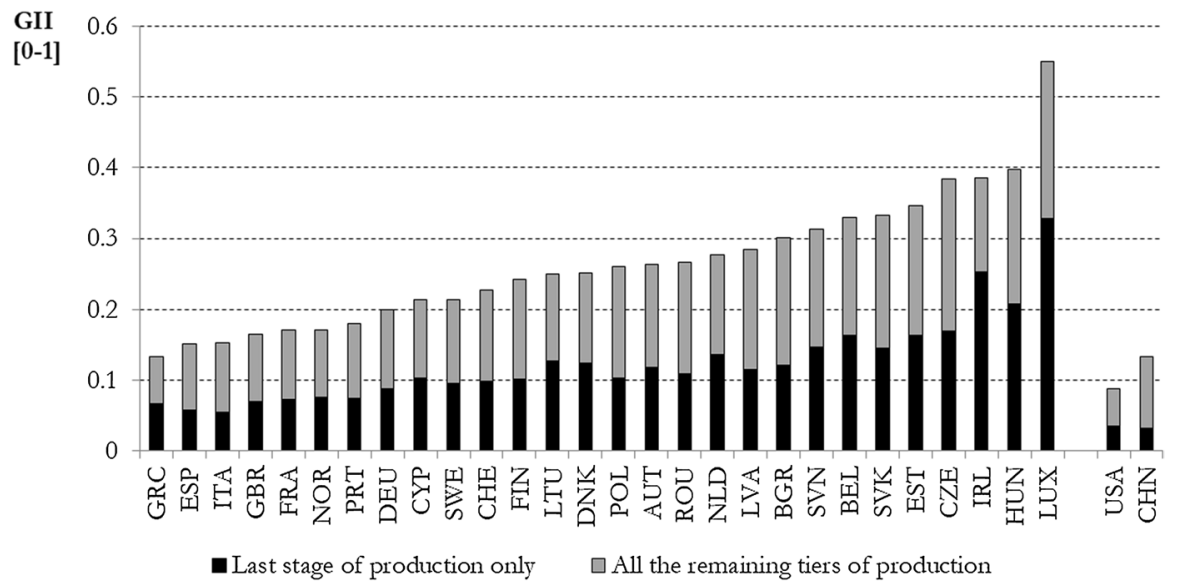

Fig. 1 Global import intensity of production (GII, index 0-1)-28 European countries versus the U.S. and China. Notes: Average values calculated across 56 industries and weighted by industrial value added $\left(V A_{i j t}\right)$. GII calculated as in Eq. 1. GII is a sum of the values for the last stage of production only and of all the remaining tiers of production. 28 European countries (Europe 28) included in the sample: $W$ Western Europe (AT, BE, CH, DE, DK, FI, FR, IE, IT, NL, NO, SE, UK); $S$ - Southern Europe (CY, ES, EL, PT); CEECs-Central and Eastern European Countries (BG, CZ, EE, HU, LT, LU, LV, PL, RO, SI, SK). Source: own calculations based on WIOD (release Nov 2016) and Timmer et al. (2016) methodology

employed in the last stage of production) can severely underestimate the importance of global sourcing and its indirect effects on domestic labour markets.

Some of the industries are much more dependent on foreign inputs than the others-global import intensity of services production tends to be much lower than for goods (Timmer et al. 2016: 4). Table 2 reports values of GII for the whole economy (all industries) and by sectors, for comparison we show the data typical for Europe 28 and the three subgroups of European countries, split into Western (W), Southern (S) and Central and Eastern (CEECs) European countries in 2014. It is clear that $G I I$ is the highest in manufacturing industries (for instance, in Western Europe GVC imports account for $42 \%$ of final manufacturing production), but the ratio of imported intermediates to the final output is also considerable in services. In Europe, value chains finalised in CEECs countries are more dependent on imported inputs than in the case of Western or Southern European countries. This is a sign of significant involvement of CEECs into GVCs.

Our further input is to compute the variants of GII which measure the reliance of the value chain linked to the production of $z$ on intermediates coming from different subgroups of countries. At every backward stage of production, we use the information on the source (country) of intermediates, and sum them over those coming from: high income countries only $\left(G I I^{H I C}\right)$ and from selected developing countries only $\left(G I I^{D E V}\right)$, encompassing China and India. ${ }^{22}$ In particular, using the latter

\footnotetext{
22 Specifically, they are calculated on the basis of imports from $H I C$ (or from $D E V$ ) in any upstream stage of production. The computation proceeds by backward movement along the value chain and identification of the source of imports in every stage. The sum is then done stepwise. This means that there are mixed backward linkages via high-income and non-high-income countries, while $G I I^{H I C}$ and $G I I^{D E V}$
} 
Table 2 Global import intensity of production (GII, index 0-1), 2014 - by sectors. Source Own calculations based on WIOD (release Nov 2016) and Timmer et al. (2016) methodology

\begin{tabular}{llll}
\hline Country sample & All industries & Manufacturing & Services \\
\hline World & 0.16 & 0.29 & 0.11 \\
Europe28 & 0.20 & 0.42 & 0.13 \\
Western Europe $(W)$ & 0.20 & 0.41 & 0.14 \\
Southern Europe $(S)$ & 0.15 & 0.40 & 0.09 \\
$C E E C s$ & 0.30 & 0.54 & 0.19 \\
\hline
\end{tabular}

Average values weighted by industrial value added $\left(V A_{i j t}\right)$. GII calculated as in Eq. 1. Country groups: $W$-Western Europe (AT, BE, CH, DE, DK, FI, FR, IE, IT, NL, NO, SE, UK); $S$-Southern Europe (CY, ES, EL, PT); CEECs - Central and Eastern European Countries (BG, CZ, EE, HU, LT, LU, LV, PL, RO, SI, SK)

measure we will assess direct and indirect effects of production dependence on the South countries characterised by lower labour costs. According to the values reported in Table 3 (Panel B) GVC imports coming from these developing countries account for a small share of final output-in the word it is only 3\% while in Europe even less (2\%). In manufacturing it is $6 \%$, so still not much. At the same time, values of $G I I^{H I C}$ are considerably higher than $G I^{D E V}$ : in Europe, on average, the value of imported intermediates employed along the value chain and coming from other well developed economies accounts for $14 \%$ of final output (31\% in manufacturing). ${ }^{23}$ It means that given the magnitude of the dependence on developing countries inputs, the negative consequences of imports coming from these countries are likely to be overvalued.

Cross-country variability in GII, as well as the changes over time (2005-2014, the years of our analysis) are shown in Table 4. Additionally, to show the importance of the proper backward measurement of foreign inputs, we report the values of GII_tierl encompassing imports from first-tier suppliers only and vertical specialization. The interpretation of the GII's values is as follows: for instance, one dollar of goods and services finalized in Germany (DE) generated around 16 dollar cent of imports worldwide in 2005 increasing to 20 dollar cent in 2014. At the same time, imported intermediates used in the last stage of production only, accounted for 7 cents in 2005 and 9 cents in 2014 per each one dollar of final German production. For most of the countries (the only exceptions are Sweden, SE and Spain, ES) the change in the measures has been positive, which is a clear sign of increasing GVC involvement. It can be either due to the imports rise in any stage of production, or

\section{Footnote 22 (continued)}

isolate the parts of the chain depending on imports from $H I C$ and $D E V$ respectively. Consequently, the two (plus imports from RoW) add up to the total GII. HIC (high income countries)=AUS, AUT, BEL, CAN, HRV, CYP, CZE, DNK, EST, FIN, FRA, DEU, GRC, HUN, IRL, ITA, JPN, KOR, LVA, LTU, LUX, MLT, NLD, NOR, POL, PRT, SVK, SVN, ESP, SWE, CHE, TWN, GBR, USA; DEV (developing countries $)=\mathrm{BRA}$, BGR, CHN, IND, IDN, MEX, ROM, RUS, TUR; RoW=world -43 countries present in WIOD2016 = world $-H I C-D E V$. The classification of countries is based on the World Bank's list of economies (July 2016).

23 Like GII, GIItierl can also be divided into three groups of source countries. The average value of GIItierl (for all countries/sectors/years in the sample together) is 0.12 and most is from high-income countries (mean value of GIItier1_HIC $=0.09, G I I t i e r 1 \_D E V=0.017$ and GII_tier1_RoW=0.016). 
Table 3 Global import intensity of production $(G I I), 2014-$ split by the source of intermediate inputs along the value chain $\left(G I I^{H I C}\right.$ and $\left.G I I^{D E V}\right)$. Source: Own calculations based on WIOD (release Nov 2016) and Timmer et al. (2016) methodology

\begin{tabular}{|c|c|c|c|}
\hline Panel A & $G I I^{H I C}$ & & \\
\hline Country sample & All industries & Manufacturing & Services \\
\hline World & 0.09 & 0.16 & 0.06 \\
\hline Europe28 & 0.14 & 0.31 & 0.10 \\
\hline Western Europe (W) & 0.14 & 0.30 & 0.10 \\
\hline Southern Europe (S) & 0.09 & 0.25 & 0.06 \\
\hline CEECs & 0.21 & 0.37 & 0.14 \\
\hline Panel B & $G I I^{D E V}$ & & \\
\hline Country sample & All industries & Manufacturing & Services \\
\hline World & 0.03 & 0.06 & 0.02 \\
\hline Europe28 & 0.02 & 0.06 & 0.02 \\
\hline Western Europe (W) & 0.02 & 0.05 & 0.02 \\
\hline Southern Europe (S) & 0.02 & 0.06 & 0.01 \\
\hline CEECs & 0.04 & 0.09 & 0.03 \\
\hline Panel C & $G I I^{R o W}$ & & \\
\hline Country sample & All industries & Manufacturing & Services \\
\hline World & 0.03 & 0.07 & 0.02 \\
\hline Europe28 & 0.03 & 0.06 & 0.02 \\
\hline Western Europe (W) & 0.04 & 0.05 & 0.02 \\
\hline Southern Europe (S) & 0.03 & 0.10 & 0.02 \\
\hline CEECs & 0.04 & 0.07 & 0.03 \\
\hline
\end{tabular}

As under Table 1. HIC (high income countries) =AUS, AUT, BEL, CAN, HRV, CYP, CZE, DNK, EST, FIN, FRA, DEU, GRC, HUN, IRL, ITA, JPN, KOR, LVA, LTU, LUX, MLT, NLD, NOR, POL, PRT, SVK, SVN, ESP, SWE, CHE, TWN, GBR, USA; DEV (developing countries) = BRA, BGR, CHN, IND, IDN, MEX, ROM, RUS, TUR; $R o W=$ world -43 countries present in WIOD2016=world $-H I C-D E V$

due to new stages of production (with similar import requirements) added to GVC causing its lengthening.

\subsection{Microdata and descriptive statistics on wages}

The micro-level data for our empirical analysis comes from EU-SILC database (Statistics on Income and Living Conditions) obtainable from Eurostat. ${ }^{24}$ The EU-SILC provides comparable cross-sectional and longitudinal multidimensional microdata

\footnotetext{
${ }^{24}$ The access to EU-SILC and other microdata from Eurostat is granted to researchers on the bases of respecting rules of the confidentiality. This study is based on data from Eurostat, EU-SILC, EUSILC UDB 2015-version 1 of August 2016 - the access has been granted by the Eurostat under the grant agreement 64/2013-LFS-EU-SILCSES. The responsibility for all conclusions drawn from the data lies entirely with the authors.
} 
Table 4 Import intensity of production based on first tier imports only (GII_tierl) and including all imports in the GVC (GII), vertical specialization-by country (Europe28). Source: own calculations based on WIOD (release Nov 2016)

\begin{tabular}{|c|c|c|c|c|c|c|c|c|c|}
\hline \multirow[t]{2}{*}{ Country } & \multicolumn{2}{|l|}{ GII } & \multicolumn{2}{|c|}{ GII_tier1 } & \multicolumn{2}{|c|}{$V S / E x p$} & \multicolumn{3}{|c|}{ Change 2005-2014 [in \%] } \\
\hline & 2005 & 2014 & 2005 & 2014 & 2005 & 2014 & GII & GII_tierl & $V S / \operatorname{Exp}$ \\
\hline \multicolumn{10}{|c|}{ Western Europe $(W)$} \\
\hline AT & 0.23 & 0.26 & 0.11 & 0.12 & 0.17 & 0.19 & 14.3 & 5.7 & 8.4 \\
\hline $\mathrm{BE}$ & 0.26 & 0.33 & 0.13 & 0.16 & 0.19 & 0.24 & 28.1 & 27.3 & 25.1 \\
\hline $\mathrm{CH}$ & 0.21 & 0.23 & 0.09 & 0.10 & 0.16 & 0.16 & 7.8 & 5.4 & 4.4 \\
\hline $\mathrm{DE}$ & 0.16 & 0.20 & 0.07 & 0.09 & 0.11 & 0.13 & 27.6 & 25.9 & 21.5 \\
\hline DK & 0.22 & 0.25 & 0.11 & 0.12 & 0.17 & 0.18 & 13.6 & 10.6 & 9.9 \\
\hline FI & 0.22 & 0.24 & 0.09 & 0.10 & 0.17 & 0.18 & 10.5 & 8.6 & 7.1 \\
\hline FR & 0.14 & 0.17 & 0.06 & 0.07 & 0.10 & 0.12 & 25.4 & 22.1 & 15.2 \\
\hline UK & 0.14 & 0.16 & 0.07 & 0.07 & 0.11 & 0.12 & 17.6 & 3.8 & 11.7 \\
\hline IE & 0.31 & 0.39 & 0.18 & 0.25 & 0.26 & 0.30 & 23.7 & 39.7 & 17.4 \\
\hline IT & 0.13 & 0.15 & 0.05 & 0.06 & 0.10 & 0.11 & 17.8 & 11.1 & 10.5 \\
\hline LU & 0.47 & 0.55 & 0.28 & 0.33 & 0.39 & 0.46 & 17.6 & 16.8 & 17.2 \\
\hline NL & 0.21 & 0.28 & 0.11 & 0.14 & 0.16 & 0.20 & 33.4 & 23.6 & 25.2 \\
\hline NO & 0.14 & 0.17 & 0.06 & 0.08 & 0.10 & 0.12 & 25.1 & 21.5 & 21.4 \\
\hline SE & 0.21 & 0.21 & 0.10 & 0.10 & 0.16 & 0.15 & 2.2 & -0.5 & -1.7 \\
\hline \multicolumn{10}{|c|}{ Southern Europe $(S)$} \\
\hline $\mathrm{CY}$ & 0.20 & 0.21 & 0.10 & 0.10 & 0.15 & 0.15 & 9.0 & 1.3 & 2.1 \\
\hline ES & 0.16 & 0.15 & 0.06 & 0.06 & 0.13 & 0.11 & -8.1 & -9.9 & -11.5 \\
\hline EL & 0.12 & 0.13 & 0.06 & 0.07 & 0.09 & 0.10 & 12.9 & 12.8 & 6.4 \\
\hline PT & 0.17 & 0.18 & 0.07 & 0.07 & 0.13 & 0.13 & 8.8 & 8.6 & 2.4 \\
\hline \multicolumn{10}{|c|}{ Central\&Eastern Europe (CEECs) } \\
\hline BG & 0.27 & 0.30 & 0.11 & 0.12 & 0.21 & 0.22 & 10.2 & 7.6 & 2.7 \\
\hline $\mathrm{CZ}$ & 0.29 & 0.38 & 0.12 & 0.17 & 0.22 & 0.27 & 30.8 & 36.1 & 23.2 \\
\hline $\mathrm{EE}$ & 0.31 & 0.35 & 0.15 & 0.16 & 0.23 & 0.24 & 10.7 & 10.2 & 3.0 \\
\hline $\mathrm{HU}$ & 0.30 & 0.40 & 0.15 & 0.21 & 0.23 & 0.28 & 30.5 & 35.4 & 22.7 \\
\hline LT & 0.22 & 0.25 & 0.11 & 0.13 & 0.17 & 0.18 & 15.3 & 12.0 & 8.1 \\
\hline LV & 0.25 & 0.28 & 0.11 & 0.12 & 0.19 & 0.20 & 13.2 & 2.6 & 7.1 \\
\hline PL & 0.21 & 0.26 & 0.09 & 0.10 & 0.15 & 0.18 & 26.3 & 16.6 & 18.6 \\
\hline RO & 0.24 & 0.27 & 0.11 & 0.11 & 0.18 & 0.19 & 8.8 & -0.1 & 4.8 \\
\hline SI & 0.27 & 0.31 & 0.12 & 0.15 & 0.23 & 0.23 & 8.1 & 2.5 & -0.3 \\
\hline SK & 0.31 & 0.33 & 0.14 & 0.15 & 0.19 & 0.22 & 18.2 & 15.9 & 13.1 \\
\hline
\end{tabular}

Average values weighted by industrial value added $\left(V A_{i j t}\right)$. GII (Timmer et al. 2016) calculated as in Eq. 1. VS/EXP - vertical specialisation measured as the ratio of foreign value added $(F V A)$ and pure double counting from foreign sources in export (Koopman et al. 2014) 
on income, poverty, social exclusion and living conditions, and is thus suitable for cross-country comparisons. ${ }^{25}$ In this study we use cross-sectional type of data provided by EU-SILC (optionally, longitudinal data is available but it lacks some crucial variables needed in our empirical analysis, such as the sector of employment used to merge micro-data with sector-level data on GII). Data are gathered in two types of files depending on the level of response: individual and household ones. We combine individual files (personal data and personal register) with household information (household data and household register) on the basis of the following matching variables: year, country, individual id and household id. Our analysis is performed on the pooled waves of EU-SILC data covering the years 2005-2014 ${ }^{26}$ and 28 European countries. ${ }^{27}$

The key variable of interest (our dependent variable) - hourly wage-is computed on the basis of variables from EU-SILC data files. Using the information on gross annual employee income ${ }^{28}$ the number of months worked during the income reference year and the average number of hours worked per week we are able to calculate hourly earnings (gross hourly wages) with the assumption of the average number of 4.2 weeks per one worked month. ${ }^{29}$ Alternatively (we will use this variable for the robustness checks), we have run additional estimations using another way of calculating the dependent variable. Instead of hourly wages we used total annual income, i.e. employees' gross cash or quasi-cash income (monetary compensation of employees in cash payable by the employer). ${ }^{30}$ Wages are expressed in EUR with the use of conversion rate provided in EU-SILC. Additionally, we use HICP from Eurostat to report wages in real terms (HICP 2015=100).

For the purpose of our analysis we employ other micro-level variables from EUSILC which are important for the determination of wages. The set of individual characteristics consist of: sex, age, marital status, education (based on the highest

\footnotetext{
${ }^{25}$ The documentation of EU-SILC can be found at: https://ec.europa.eu/eurostat/web/microdata/europ ean-union-statistics-on-income-and-living-conditions. To transform original csv files into the Stata format we have used the routines from Gesis (prepared by Heike Wirth, https://www.gesis.org/en/missy/ materials/EU-SILC/setups).

${ }^{26}$ Theoretically the data for the 2015 is also present, however for the limited number of countries. There are some differences between data collected under different waves. The documentation we rely on is provided (along with the data files) in EC (2016).

${ }^{27}$ Out of 32 countries covered by EU-SILC, two are not reported in WIOD (Iceland and Serbia), while for Malta and Croatia the number of missing information referring to hourly wages and specific aggregation of other variables do not allow us to include them in the final sample.

${ }^{28}$ We take into account gross employee cash or near cash income which refers to the monetary compensation of employees in cash payable by an employer to an employee. Among others it includes: wages and salaries paid in cash for time worked or work done, holiday payments, payments for overtime, additional payments e.g.: thirteenth month payment, payment based on one's productivity, commissions, tips and gratuities. Gross means that neither taxes nor social contributions have been deducted.

${ }^{29}$ The assumption of an average of 4.2 weeks worked per month reflects minimum yearly holidays. However, we have run an additional robustness check assuming 52/12 $=4.33$ weeks per month instead of 4.2. The results, which do not differ substantially from the benchmark, are reported in Table $2 \mathrm{~A}$ in Appendix.

${ }^{30}$ This includes: wages and salaries for time worked or work done, holiday pay, overtime, and additional payments such as "thirteenth month," productivity pay, commissions, tips and gratuities. The results taking annual income as dependent variable are reported in Table 2A in Appendix.
} 
ISCED level attained and reclassified into groups with high education: ISCED level $6,7$ and 8 or less than high education: ISCED from 0 to 4$){ }^{31}$ Labour characteristics include: the information on the size of the company an employee is working for (micro firm if less than 11 persons are employed, medium: 11-49 employees and big-50 or more employees), the type of contract (permanent versus temporal, including work contract of limited duration), managerial position (if the work includes supervisory responsibilities), the sector of employment (NACE Rev 1.1 for 2004-2007 and NACE Rev.2 for 2008 onwards) and occupation (following 2 digit ISCO-88 classification till 2011 and ISCO-08 afterwards). ${ }^{32}$

We restrict our sample to full time workers within working age population 18-65 for whom we have the data allowing us to compute wage measure as well as the information about their occupation and sector of employment. Additionally, we do not take into account armed force occupations. In order to eliminate outlier values in our sample, we correct top and bottom distribution of wages. At the bottom we trim the distribution at the 1/100 of country-specific mean and at the bottom wages greater than ten times the national median are set to ten times the national median. The trimming is performed for each year and each country separately. ${ }^{33}$ In Table 1A in the online appendix we report summary statistics of all the micro-level variables. Average worker in our sample is 41 years old with 19 years of work experience and earns 14 euro per hour; $60 \%$ of workers are males and $32 \%$ have tertiary education; $56 \%$ are married, almost half of the workers are employed in a big firm, $89 \%$ have permanent contract while $11 \%$ work with a temporary job contract, $28 \%$ hold managerial position which includes formal responsibility for supervising a group of other employees also only during some times and doing some of the work. ${ }^{34}$

An important feature of our data is that we are able to quantify the routine content of jobs of particular workers. For this purpose we use country-specific routine task intensity indices (RTIs) which not only reflect the differences in routinisation between particular occupations, but also between countries (Lewandowski et al.

\footnotetext{
31 Unfortunately, the data on experience (the number of years spent in paid work) is missing for: DK, EL (years 2005-2009), FI, HU, NO, SE, UK (years 2005-2009) so we do not include this variable in our wage regression. However, the correlation between age and experience is high (0.9), so age should be a good proxy for work experience as well.

32 Our concordance between sectors and occupations takes into account the changes in classifications over time. For the period of time when the old classification existed we match data of individual workers from EUSILC with other variables e.g. sectoral ones based on that old classification, after the classification changed we use the most recent schemes.

33 Alternatively, we considered to trim the distribution at the bottom at 1 st percentile and at the top at the 99th percentile of country and year specific wages. This does not change the results effectively.

34 The comparison of these values with data reported by Eurostat proves that our sample reflects quite well the European labour market. For instance, according to the official statistics $34.2 \%$ of the $25-54$ olds in the EU-28 had completed tertiary education (source: Eurostat, edat_lfs_9903, 2017); the proportion of employees aged 15-74 in the EU-28 with a contract of limited duration (fixed-term employment) was 14.2\% (source: Eurostat, lfsa_esegt, 2016), lower employment rates are observed for women than men (gender employment gap equals to 11.5 p.p., source: Eurostat, Ifsa_ergan 2017).
} 


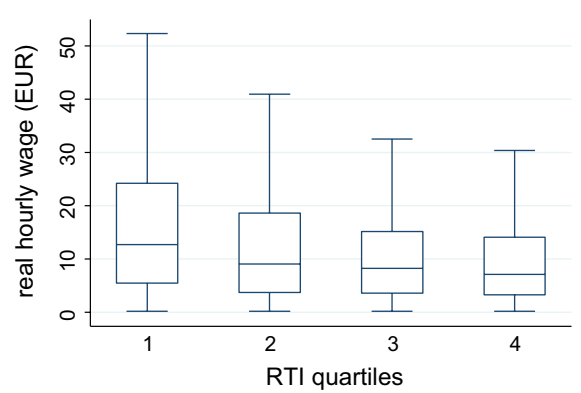

1st quartile of $\mathrm{RTI}=$ the least routine, 4 th quartile of $\mathrm{RTI}=$ the most routine

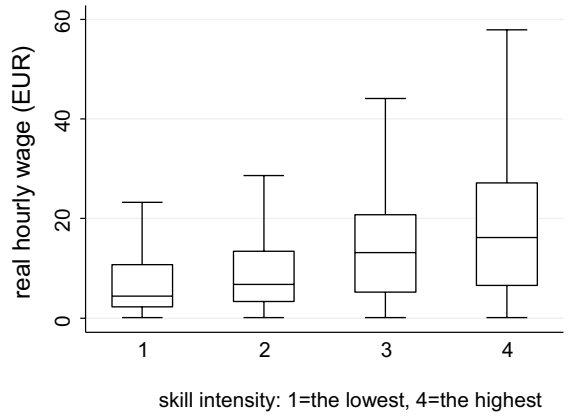

Fig. 2 Wages by job routinisation intensity and by skill intensity (Europe 28, 2014). Source: Own calculations based on EU-SILC. RTI quartiles based on country-specific indices of job routinisation from Lewandowski et al. (2019), skill categories based on mapping main ISCO groups into skill groups according to ILO (2012)

2019). ${ }^{35}$ RTIs are based on survey data from OECD's PIAAC, the World Bank's Skills Toward Employment and Productivity (STEP), plus the China Urban Labor Survey (CULS), which closely mirrors the occupational task measurements in Acemoglu and Autor (2011) based on the U.S. O*NET data. Lewandowski et al. (2019) document that the relative importance of various tasks differs between countries for workers performing seemingly similar jobs. Given that they find substantial crosscountry differences in the content of work, also within occupations, we use RTIs that are country-occupation-specific and accordingly measure differences in routinisation between countries and between occupations. ${ }^{36}$

Given that we are primarily interested in the evolution of wages, in Fig. 2 we show boxplots of wages by task quartile and, additionally, by skill group. For this purpose, we compute country-specific quartiles of RTI indices which allows us to divide workers into four categories where the bottom category contains workers with the lowest degree of job routinisation (1st quartile of RTI) while the top category refers to workers with the highest degree of job routinisation (4st quartile of RTI). Importantly, thanks to the use of country-specific routinisation indices, the job routinisation of each worker is assessed here with respect to the national distribution

\footnotetext{
35 We would like to thank Piotr Lewandowski from IBS Warsaw for sharing their country-specific indices of routinisation (see Hardy et al. 2018a for methodological details on their computation). The set of indices is available for 42 countries that participated in PIAAC, STEP and CULS surveys. For some of the countries we attribute the values of the most similar country (in terms of economic development, location and size).

${ }^{36}$ Having country- and occupation-specific RTI, the differences in wage distribution by RTI quartiles in the countries examined are likely to be due to the differences in the composition of occupations across countries and to the differences in the routinisation measure of occupations. The importance of country heterogeneity in measuring task contents has recently been pointed out by other authors as well-for instance, de Arcangelis and Mariani (2019) document that multi-country variability of PIAAC-based task indexes for European countries is non-negligible and recommend these measures for multi-country analysis (as in our paper).
} 
Table 5 Wages by job routinisation intensity (Western Europe, Southern Europe and CEECs, 2014). Source: Own calculations based on EU-SILC

\begin{tabular}{llccc}
\hline Country sample & $\begin{array}{l}\text { RTI quartile 1 } \\
(=\text { the least routine) }\end{array}$ & RTI quartile 2 & RTI quartile 3 & $\begin{array}{l}\text { RTI quartile } \\
4 \text { (= the most } \\
\text { routine })\end{array}$ \\
\hline Western Europe (W) & 23.87 & 18.92 & 14.74 & 14.20 \\
Southern Europe (S) & 14.98 & 10.51 & 9.10 & 7.74 \\
CEECs & 5.13 & 3.20 & 3.25 & 3.04 \\
\hline
\end{tabular}

RTI quartiles based on country-specific indices of routine task intensity of occupations from Lewandowski et al. (2019)

of tasks. Skill groups (1-4 where 1 is the lowest and 4 the highest) are defined on the basis of ILO (2012) methodology mapping major ISCO groups to skill levels. Unsurprisingly, higher wages are paid to workers performing occupations which require high skills and are less routine. The box plots ${ }^{37}$ also show noticeable dispersion of wages within each category.

There are of course noticeable cross-country differences in wages. In Table 5 we show average wages, by RTI quartile, in the three groups of European countries (in Table 11A in the online Appendix we show analogous country-specific values). Unsurprisingly, the highest wages are reported for those performing low routine occupations, meaning the first quartile of RTI (e.g. in Western Europe the average wage in such occupations equals almost 24 euro per hour, while in CEECs only 5 euro). Workers employed in the most routine intensive jobs earn considerably less. This tendency is stable across countries.

Is this a sign that major GII is among significant determinants of wages, once all the other factors influencing wage determination process are accounted for? We will address this question in the next section.

\section{Empirical model and estimation results}

\subsection{The results}

Our empirical strategy is based on the estimation of individual wage regression augmented with the measure of the dependence of domestic production on foreign inputs-GII-typical for sector in which a given person is employed. Similar approach has been adopted (among others) by Baumgarten et al. (2013), Geishecker et al. (2010) and Ebenstein et al. (2014) who merged micro-level data on labor market outcomes with sectoral observation on offshoring intensity or Parteka and Wolszczak-Derlacz (2019) who combined individual wage data with statistics on sectoral foreign value added share.

\footnotetext{
37 The line inside each box corresponds to the median wage value, box edges show 25 th and 75 th percentile while the lines extending from the box indicate the variability outside the upper and lower quartiles.
} 
First, we estimate the following model:

$$
\operatorname{lnwage}_{i j o c t}=\alpha+\beta X_{i t}+\gamma J o b_{i t}+\delta R T I_{o c}+\theta G I I_{j c t}+\mu \operatorname{lnProd}_{j c t}+D_{t}+D_{j}+D_{c}+\varepsilon_{i j o c t}
$$

where $i$ denotes a worker employed in sector $j$ in occupation $o$ in country $c$ at time $t$. We regress the log of the gross hourly wage (lnwage) on a set of personal characteristics X (sex, age, age ${ }^{2}$, marital status, education), job characteristics Job (firm size, type of the contract, managerial position) and information on the routine content of occupation RTI (routine task intensity index). We augment the model with the information on global import intensity $(G I I$ where $G I I=[0-1])$ so coefficient $\theta$ represents the elasticity of wages with respect to globally measured dependence on foreign inputs. As more productive sectors are likely to pay higher wages, in some specifications we also include productivity (Prod), measured as the ratio of real sectoral value added to the total number of hours worked by employees, as an additional industry-level control. Additionally we include time effects $D_{t}$ (controlling for time specific economic fluctuations, e.g. 2008/2009 crisis), industry dummies $D_{j}$ (allowing for all the remaining industry-specific characteristics or wage regulations) and country dummies $D_{c}$ (picking up all country-specific conditions, including labour market institutions and wage-setting mechanisms). ${ }^{38}$

Equation (2) is estimated with the use of weighted regression (with normalized weights based on original personal weights provided by EU-SILC and normalized by the number of observations per country to sum up to 10,000 within each country) and robust standard errors which are clustered at the country-industry level. Given the potential endogeneity between the use of foreign inputs (and thus offshoring activity) and wages, we adopt instrumental variables estimation. ${ }^{39} \mathrm{We}$ instrument the global import intensity of a country by the contemporaneous composition of global imports of other countries related to the lagged value of their final product, which is close in spirit to the approach of Autor et al. (2013). Indeed, we find that instruments are correlated with GII and orthogonal to changes of individual workers' wages. The choice of the instruments is confirmed by under- and weak identification tests.

The first two columns of Table 6 present estimation results of the basic specification (Eq. 2) based on pooled OLS, they differ in a set of explanatory variables (information on contract type and managerial position are not available for all workers). In columns 3 and 4 we report analogous IV estimations. On average, male, older, married workers with higher education earn more. Additionally, higher wages are characteristic for employees working in medium and big companies (in relation

\footnotetext{
38 In the robustness section we will add to the estimation more information about the characteristics of labour market institutions which vary across countries. The results are reported in Table 4A. Additionally, we have considered the estimations including a dummy for occupations but as our RTI measure is country- and occupation-specific, we find the specification with country and occupation dummies to be overly restrictive. The results are reported in Table R3.

39 Although we try to take the endogeneity problem into account, causal interpretation should be made with caution. Our empirical analysis is based on pooled waves of EU-SILC data for 2005-2014, which is not a panel where individuals are observed over time.
} 
Table 6 Estimation results (1) - GII among other determinants of wages in Europe. Source Own elaboration based on data from EU-SILC and WIOD

\begin{tabular}{|c|c|c|c|c|}
\hline Dep.var: log hourly wage (gross) & $\begin{array}{l}\text { OLS } \\
\text { (1) }\end{array}$ & $\begin{array}{l}\text { OLS } \\
\text { (2) }\end{array}$ & $\begin{array}{l}\text { IV } \\
\text { (3) }\end{array}$ & $\begin{array}{l}\text { IV } \\
\text { (4) }\end{array}$ \\
\hline $\operatorname{Sex}(=1$ if male $)$ & $\begin{array}{l}0.167 * * * \\
{[0.008]}\end{array}$ & $\begin{array}{l}0.163 * * * \\
{[0.008]}\end{array}$ & $\begin{array}{l}0.168 * * * \\
{[0.008]}\end{array}$ & $\begin{array}{l}0.163 * * * \\
{[0.008]}\end{array}$ \\
\hline Age (years) & $\begin{array}{l}0.048 * * * \\
{[0.003]}\end{array}$ & $\begin{array}{l}0.041 * * * \\
{[0.002]}\end{array}$ & $\begin{array}{l}0.048 * * * \\
{[0.003]}\end{array}$ & $\begin{array}{l}0.041 * * * \\
{[0.002]}\end{array}$ \\
\hline $\mathrm{Age}^{2}$ & $\begin{array}{l}-0.000^{* * *} \\
{[0.000]}\end{array}$ & $\begin{array}{l}-0.000^{* * *} \\
{[0.000]}\end{array}$ & $\begin{array}{l}-0.000^{* * *} \\
{[0.000]}\end{array}$ & $\begin{array}{l}-0.000 * * * \\
{[0.000]}\end{array}$ \\
\hline Marital status (=1 if married) & $\begin{array}{l}0.032 * * * \\
{[0.003]}\end{array}$ & $\begin{array}{l}0.026 * * * \\
{[0.003]}\end{array}$ & $\begin{array}{l}0.031 * * * \\
{[0.003]}\end{array}$ & $\begin{array}{l}0.026 * * * \\
{[0.003]}\end{array}$ \\
\hline Education (=1 if high) & $\begin{array}{l}0.208 * * * \\
{[0.007]}\end{array}$ & $\begin{array}{l}0.199 * * * \\
{[0.007]}\end{array}$ & $\begin{array}{l}0.208 * * * \\
{[0.007]}\end{array}$ & $\begin{array}{l}0.199 * * * \\
{[0.007]}\end{array}$ \\
\hline Firm size (=1 if big) & $\begin{array}{l}0.259 * * * \\
{[0.010]}\end{array}$ & $\begin{array}{l}0.191 * * * \\
{[0.008]}\end{array}$ & $\begin{array}{l}0.259^{* * *} \\
{[0.010]}\end{array}$ & $\begin{array}{l}0.192^{* * *} \\
{[0.008]}\end{array}$ \\
\hline Firm size (=1 if medium) & $\begin{array}{l}0.167 * * * \\
{[0.009]}\end{array}$ & $\begin{array}{l}0.100 * * * \\
{[0.007]}\end{array}$ & $\begin{array}{l}0.167 * * * \\
{[0.009]}\end{array}$ & $\begin{array}{l}0.101^{* * *} \\
{[0.007]}\end{array}$ \\
\hline ln_Prod (VA/H) & $\begin{array}{l}0.106^{* * * *} \\
{[0.030]}\end{array}$ & $\begin{array}{l}0.126 * * * \\
{[0.029]}\end{array}$ & $\begin{array}{l}0.102 * * * \\
{[0.030]}\end{array}$ & $\begin{array}{l}0.123 * * * \\
{[0.029]}\end{array}$ \\
\hline$R T I$ & $\begin{array}{l}-0.377 * * * \\
{[0.010]}\end{array}$ & $\begin{array}{l}-0.347 * * * \\
{[0.010]}\end{array}$ & $\begin{array}{l}-0.378^{* * *} \\
{[0.010]}\end{array}$ & $\begin{array}{l}-0.347 \text { **** } \\
{[0.010]}\end{array}$ \\
\hline GII & $\begin{array}{l}-0.153^{* *} \\
{[0.074]}\end{array}$ & $\begin{array}{l}-0.149 * \\
{[0.077]}\end{array}$ & $\begin{array}{l}-0.240 * * * \\
{[0.075]}\end{array}$ & $\begin{array}{l}-0.211^{* * * *} \\
{[0.078]}\end{array}$ \\
\hline Job contract (= 1 if permanent) & & $\begin{array}{l}0.212 * * * \\
{[0.017]}\end{array}$ & & $\begin{array}{l}0.213^{* * * *} \\
{[0.018]}\end{array}$ \\
\hline Job position ( $=1$ if managerial) & & $\begin{array}{l}0.125^{* * *} \\
{[0.004]}\end{array}$ & & $\begin{array}{l}0.125^{* * *} \\
{[0.004]}\end{array}$ \\
\hline $\mathrm{R}^{2}$ & 0.76 & 0.8 & 0.76 & 0.8 \\
\hline $\mathrm{N}$ & $1,217,953$ & $1,105,538$ & $1,213,922$ & $1,101,866$ \\
\hline Under-identification & & & 0.00 & 0.00 \\
\hline Weak identification & & & $472,352.6$ & $444,775.6$ \\
\hline Hansen J (p-value) & & & 0.42 & 0.51 \\
\hline
\end{tabular}

Normalised weighted regression with robust standard errors (in parentheses), clustered at the countryindustry level, the weights are based on personal cross-sectional weights (from EU-SILC) normalised by the number of observation per country (see main text for the details); * $p \leq .10, * * p \leq .05$, *** $p \leq .01$. In specification (3) and (4) GII is treated as an endogenous variable, see the main text for the explanation of instrument construction. The figures reported for the under-identification test are the p-values and refer to the Kleibergen-Paap rk LM test statistic, where a rejection of the null indicates that the instruments are not under-identified. The weak identification test refers to the Kleibergen-Paap Wald rk F statistic test for the presence of weak instruments. As a 'rule of thumb' the statistic should be at least 10 for weak identification not to be considered a problem (Staiger and Stock 1997). The Hansen J test of overidentifying restrictions (null hypothesis is that the instruments are valid) refers to its p-value 
to small firms), having a permanent contact and holding managerial position which requires supervisory responsibilities (columns 2 and 4). Hence, in all specifications, the obtained coefficients concerning workers' individual and job characteristic are in line with the microeconomic theory of wage determination (the Mincerian model) to save space, in the subsequent tables we will not report them. Unsurprisingly, the degree of routinisation, measured by $R T I$, is a significant and negative determinant of wage level.

When it comes to industry-level characteristics, employment in more productive sectors is associated with higher wages while sectors with more intensive process of international production fragmentation (higher $G I I$ ) offer lower wages. Additionally, in Table 7 (and in the subsequent tables) we present the regression with plain GII and $R T I$ and also with the interaction between $G I I$ and $R T I$. In the augmented specifications (with interaction) the marginal effect of a change in GII on wages also depends on the value of $R T I$. Thus the interaction could help to clarify whether the negative relationship between GII and log wage is attenuated or magnified in countries and industries where occupations are typically more routine. The results suggest that in general the degree of routinisation is a highly robust determinant of wages (clearly the more routine the job, the lower the wage). The interaction between GII and RTI is not statistically significant, so we conclude that wages are determined by a set of microlevel variables (Mincerian framework), the type of tasks performed on the job, and GII (independent of routinisation). As reported in Table 7, the negative relationships between hourly wage and job routines and between GII and wages are not sensitive to the set of other control variables included into the model as wage determinants. The magnitude of the wage effect of GII is higher when the endogeneity is taken into account, from now on we will concentrate on IV estimations. To save space, we will report coefficients for GII, the routinisation and interaction GIIxRTI only, but all the models include personal and employment controls, industry characteristics (productivity), time, country and industry dummies. ${ }^{40}$

The basic specification was estimated on the full sample of countries, sectors and GII independently of the source country of imports. In order to understand what drives the effect of $G I I$ on wages we re-run the estimations taking into account GII computed on the base of information of inputs employed in the value chain and coming exclusively from high income countries $(H I C)$, from developing countries $(D E V)$ included in WIOD and from the RoW (in fact including mainly the aggregate for the developing world-see the note under Table 3). According to the results reported in Table 8, the negative impact of import intensity on wages is much higher

\footnotetext{
40 We have also run the estimations (with interaction term) for the four RTI quartiles-the coefficient for GII is the highest for the 4th quartile (the most routine). Additionally, in line with Baumgarten et al. (2013), we rerun the estimations including interactions between specific skill groups and either GII, RTI or both: the marginal effects of GII and $R T I$ are skill-specific and the strongest (negative) correlation is for the lowest-skilled workers. Next, we included the interactions between GII/RTI and specific occupations grouped by ISCO-08 1-digit classification, finding the heterogeneity of marginal effects of GII/ $R T I$ across occupations with stronger (negative) effects for elementary occupations and weaker effects for professionals and managers. The results are reported in Table R4, Table R5 and Table R6 in appendix, respectively. We thank the anonymous referee for these suggestions.
} 
Table 7 Estimation results (2)—GII as wage determinant in Europe (interaction with job routinisation, $R T I$ and the inclusion of extended set of control variables). Source: Own elaboration based on data from EU-SILC and WIOD

\begin{tabular}{lllll}
\hline Dep.var: log hourly wage (gross) & $(1)$ & $(2)$ & $(3)$ & $(4)$ \\
\hline$R T I$ & $-0.563^{* * *}$ & $-0.400^{* * *}$ & $-0.390^{* * * *}$ & $-0.378^{* * * *}$ \\
& {$[0.026]$} & {$[0.023]$} & {$[0.023]$} & {$[0.023]$} \\
GII & $-0.299^{* * * *}$ & $-0.279^{* * *}$ & $-0.301^{* * *}$ & $-0.316^{* * *}$ \\
& {$[0.100]$} & {$[0.090]$} & {$[0.089]$} & {$[0.089]$} \\
GII $x$ RTI & 0.101 & 0.055 & 0.033 & 0.093 \\
& {$[0.068]$} & {$[0.062]$} & {$[0.062]$} & {$[0.065]$} \\
Personal controls & No & Yes & Yes & Yes \\
Firm controls & No & No & Yes & Yes \\
Job controls & No & No & No & Yes \\
Time dummies $p$ value & 0.000 & 0.000 & 0.000 & 0.000 \\
Country dummies $p$ value & 0.000 & 0.000 & 0.000 & 0.000 \\
Industry dummies $p$ value & 0.000 & 0.000 & 0.000 & 0.000 \\
$\mathrm{R}^{2}$ & 0.72 & 0.75 & 0.76 & 0.8 \\
$\mathrm{~N}$ & $1,312,076$ & $1,304,717$ & $1,213,922$ & $1,101,866$ \\
Under-identification & 0.00 & 0.00 & 0.00 & 0.00 \\
Weak identification & $277,005.8$ & $274,132.8$ & 260,375 & $247,920.2$ \\
Hansen J (p-value) & 0.6 & 0.33 & 0.36 & 0.48 \\
\hline
\end{tabular}

Normalised weighted regression with robust standard errors (in parentheses), clustered at the countryindustry level, the weights are based on personal cross-sectional weights (from EU-SILC) normalised by the number of observation per country (see main text for the details); ${ }^{*} p \leq .10, * * p \leq .05, * * * p \leq .01$. Personal controls include: age, age2, marital status, education (the default category for education are non-high (medium /low-educated workers)), Employment controls refer to the size of the entities: the default category are small firms, Job controls refer to the type of the contract (the default category is non-permanent contract) and type of the position (the default category non- managerial). GII is treated as an endogenous variable, see the main text for the explanation of instrument construction. In all specifications time, country and industry dummies are included, p-values for the Wald tests of hypothesis that dummies' coefficients are zero. The figures reported for the under-identification test are the p-values and refer to the Kleibergen-Paap rk LM test statistic, where a rejection of the null indicates that the instruments are not under-identified. The weak identification test refers to the Kleibergen-Paap Wald rk F statistic test for the presence of weak instruments. As a 'rule of thumb' the statistic should be at least 10 for weak identification not to be considered a problem (Staiger and Stock 1997). The Hansen J test of overidentifying restrictions (null hypothesis is that the instruments are valid) refers to its p-value

when inputs employed along the production chain come from the developing countries and/or RoW (columns 4 and 6), than when GII is measured with GVC imports from high income countries (columns 1 and 2). Such a result indicates that the process of transferring production to low income (thus low wage) countries, which are characterised by lower cost of production, and then importing inputs from them along the sequential production chain force native workers to accept lower wages. Such a result is much weaker when we consider only GVC imports coming from less competitive high income countries (columns 1 and 2).

Given that our sample consists of workers from different countries and sectors, we also explore these sources of results' heterogeneity (these results are reported 
Table 8 Estimation results (3) - GII as wage determinant in Europe, split according to the source of imports along the value chain. Source Own elaboration based on data from EU-SILC and WIOD

\begin{tabular}{|c|c|c|c|c|c|c|}
\hline \multirow{3}{*}{$\begin{array}{l}\text { Dep.var: log hourly } \\
\text { wage (gross) }\end{array}$} & \multicolumn{6}{|c|}{ GII_-imports coming from: } \\
\hline & \multicolumn{2}{|c|}{$\begin{array}{l}\text { High income countries } \\
(H I C)\end{array}$} & \multicolumn{2}{|c|}{$\begin{array}{l}\text { Developing countries } \\
(D E V)\end{array}$} & \multicolumn{2}{|c|}{$\begin{array}{l}\text { Rest of the world } \\
(\text { RoW })\end{array}$} \\
\hline & (1) & (2) & (3) & (4) & (5) & (6) \\
\hline$R T I$ & $\begin{array}{l}-0.381 * * * \\
{[0.011]}\end{array}$ & $\begin{array}{l}-0.384 * * * \\
{[0.023]}\end{array}$ & $\begin{array}{l}-0.379 * * * \\
{[0.011]}\end{array}$ & $\begin{array}{l}-0.403 * * * \\
{[0.023]}\end{array}$ & $\begin{array}{l}-0.382 * * * \\
{[0.011]}\end{array}$ & $\begin{array}{l}-0.400 * * * \\
{[0.024]}\end{array}$ \\
\hline GII & $\begin{array}{l}-0.387 * * * \\
{[0.120]}\end{array}$ & $\begin{array}{l}-0.392 * * * \\
{[0.124]}\end{array}$ & $\begin{array}{l}-1.781 * * \\
{[0.718]}\end{array}$ & $\begin{array}{l}-2.169 * * \\
{[0.924]}\end{array}$ & $\begin{array}{l}-1.905^{* * *} \\
{[0.703]}\end{array}$ & $\begin{array}{l}-2.122 * * * \\
{[0.720]}\end{array}$ \\
\hline GII $x R T I$ & & $\begin{array}{l}0.016 \\
{[0.088]}\end{array}$ & & $\begin{array}{l}0.606 \\
{[0.476]}\end{array}$ & & $\begin{array}{l}0.43 \\
{[0.495]}\end{array}$ \\
\hline $\mathrm{R}^{2}$ & 0.77 & 0.77 & 0.76 & 0.76 & 0.76 & 0.76 \\
\hline $\mathrm{N}$ & $1,207,394$ & $1,207,394$ & $1,207,394$ & $1,207,394$ & $1,207,112$ & $1,207,112$ \\
\hline Under-identification & 0.00 & 0.00 & 0.00 & 0.00 & 0.00 & 0.00 \\
\hline Weak identification & $249,260.4$ & $120,640.3$ & $14,588.23$ & 8218.53 & $24,809.44$ & $12,125.69$ \\
\hline Hansen J (p-value) & 0.9 & 0.79 & 0.05 & 0.04 & 0.06 & 0.03 \\
\hline
\end{tabular}

As under Table 7. Personal and employment controls, time, country and industry dummies included in all models. HIC (high income countries) = AUS, AUT, BEL, CAN, HRV, CYP, CZE, DNK, EST, FIN, FRA, DEU, GRC, HUN, IRL, ITA, JPN, KOR, LVA, LTU, LUX, MLT, NLD, NOR, POL, PRT, SVK, SVN, ESP, SWE, CHE, TWN, GBR, USA; DEV (developing countries)=BRA, BGR, CHN, IND, IDN, MEX, ROM, RUS, TUR; RoW=world -43 countries present in WIOD2016= world $-H I C-D E V$

in online appendix B). According to the estimations of Eq. 2 conducted on sample splits, the negative and statistically significant effect of $G I I$ on wages concerns mainly workers from Western and Southern European countries (Table 1B in online appendix B) and the effect is much more pronounced for workers employed in manufacturing then in services (Table $2 \mathrm{~B}$ in online appendix B). Additionally, in a model focusing on workers in Western Europe, the interaction between GII and RTI is negative and statistically significant, which indicates that GII is connected with a sharper decline in the wages of workers doing more routine labour (the opposite is true for workers from Central and Eastern Europe (Table 1B in online appendix B). It is plausible, that this is the effect of offshoring between Western and Eastern Europe, as routine tasks are 'moved' to Eastern Europe, where the demand for workers performing them increases.Further, we simultaneously consider diverse sources of heterogeneity. Table $3 \mathrm{~B}$ reports the results for workers from Western European countries and when GII is differentiated according to the source of inputs along the value chain. The negative association between GII and wages is confirmed for workers from Western Europe and its magnitude is the highest when GVC inputs are imported from developing countries. Additionally, as reported in Table 4B, this negative effect is felt by Western European workers employed in manufacturing.

As our study seems to be the first to employ GII to measure global dependence on foreign inputs, it is thus interesting to compare our results to the ones obtained with conventional measures of value added trade and offshoring (Johnson and Noguera 2012; Koopman et al. 2014; Wang et al. 2013; Feenstra and Hanson 1999), as they 
may differ. To do so, we have computed: $O F F$ - imports of intermediate inputs in proportion to the value added of a given sector (traditional offshoring measure as in Feenstra and Hanson 1999); FVA/EXP-foreign value added in exports (derived from export decomposition following Wang et al. (2013); FVA_FIN/EXP_foreign value added used in final goods exports (Wang et al 2013); FVA_INT/EXP_-foreign value added used in intermediate exports over total exports (Wang et al. (2013); VS/ $E X P$ - vertical specialisation measured as the ratio of foreign value added $(F V A)$ and pure double counting from foreign sources $(F D C)$ to exports (Koopman et al. 2014); $V S 1 / E X P$ - vertical specialisation measured as the ratio of foreign value added $(F V A)$ plus total pure double counting (PDC) to exports (Wang et al. 2013).

As expected, our measure $(G I I)$ is closely correlated with the other measures of value added trade/offshoring (high pairwise correlation coefficients, reported in Table $\mathrm{R} 2^{41}$ ). To show how alternative measures of value added trade and offshoring work in the framework of Mincer regressions, Table 9 reports the results where these alternative measures have been included in the set of regressors, instead of GII. Additionally, in column 2 we report the results taking into account only import intensity of production measured at the last stage (GII_tierl) while GII_except_tierl (column 3) takes into account previous cross-country and cross-industry links along the entire production sequence but except the last stage (indirect exposure). The coefficients are always negative and statistically significant. In order to assess the relative strength of each of the different measures of GVC, we provide standardized regression coefficients that show the effect on wages of a one-standard-deviation increase in any given GVC measure. Comparing the results obtained with GII, GII_ tierl and GII_except_tierl, the strongest effect is for total GII while the weakest for direct exposure (GII_tierl). The differences in the magnitudes of standardised coefficients for the last stage of production and all stages except the last are not as significant, which could be due to the nature of sequential production and the interplay between various stages of the chain. However, the coefficients should be put in the perspective of the actual value of GII measures (see Table 4): the value of imported inputs used in the last stage (GII_tierl) is less than when all the backward stages of production are taken into account $(G I I)$.

\subsection{Economic significance of the results}

Based on the above results, one would conclude that the involvement of domestic industries into production fragmentation, measured globally along all the chain of production, impacts negatively mainly wages of Western European workers (once all other-individual, job, country and sectoral characteristics are controlled for).

\footnotetext{
41 The country rankings and trends based on $G I I$ and different measures of vertical specialization (FVA/ EXP, FVA_FIN/EXP, FVA_INT VS/EXP, VS1/EXP) and the traditional measure of offshoring (OFF) are similar, in keeping with strong correlation between those measures of production fragmentation (reported in Table R2 in appendix). The various methods of measuring fragmentation lead to the conclusion that the country-sectors that rely heavily on imported inputs are also those with high proportions of exported FVA.
} 


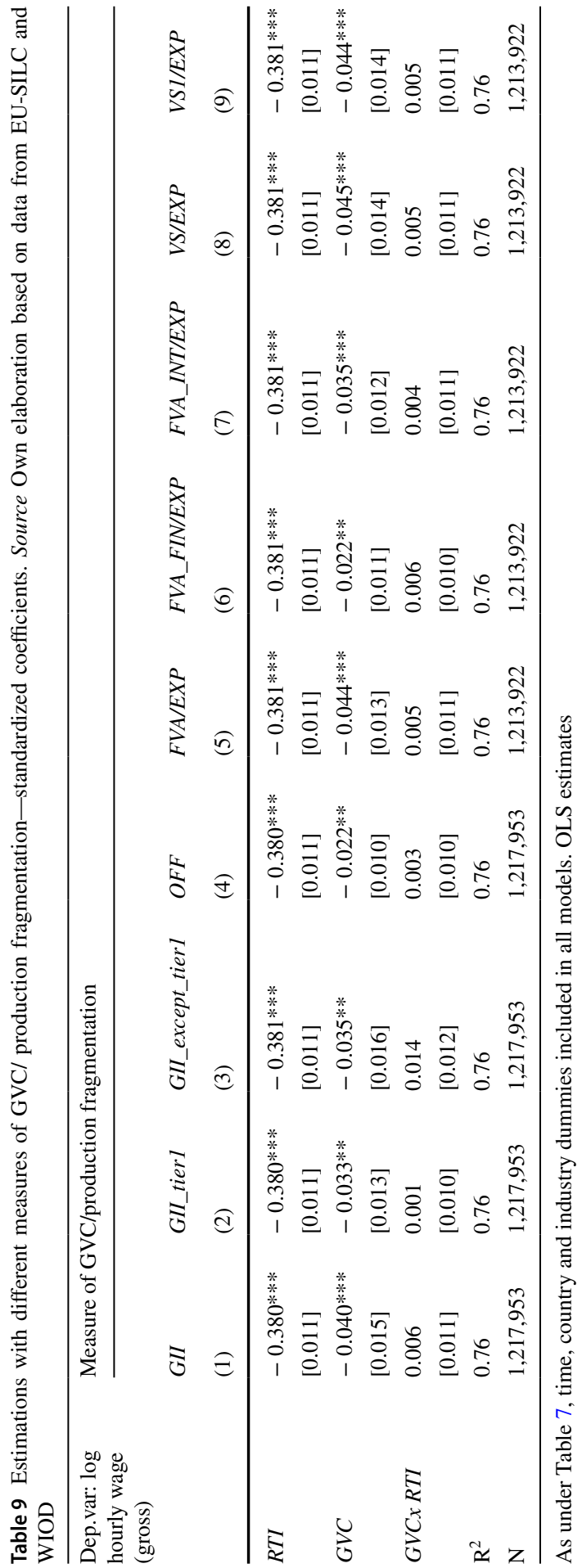


How strong are the estimated effects in economic terms? In other words, how much wages in Europe changed due to increased GII? First of all, let's remind that GII index ranges between 0 and 1 . Hence, the estimates of log-linear model (2) indicate that and increase in $G I I$ by one unit (hence by 1 , which is equivalent to a rise of $G I I$ by $100 \%$ ) is associated with a change in hourly wage by $\theta \%$. Taking into account the results for all sample (Europe28) the biggest estimated coefficient $\theta$ is equal to -0.316 (Table 7, column 4). We shall put it in the perspective of registered rise in GVC imports and data on wages in Europe. Table 10 shows the economic significance of the results (based on statistically significant estimates only reported in Tables 7, 8 and Table 3B in online appendix B) where we compare the results, split by the source of imports along the GVC, for all the sample and for Western European workers only, typically perceived in the literature as negatively exposed to the effects of production fragmentation.

According to our data, over the sample period GII (averaged over all industries) in the whole EU28 sample rose from 0.166 (=16.6\% of final output) in 2005 to $0.202(=20.2 \%)$ in 2014 , hence $G I I$ rose by 0.0354 (=3.54p.p.). Combining it with the coefficient estimate from Table 7 (column 4) and with the data on average hourly wage in the initial year (15.75 eur per hour), we find that the change in GVC imports in the period 2005-2014 resulted in average cumulated wage decrease by only 0.176 eur $[=3.54 / 100 *(-0.316) * 15.75$ eur $]$. Assuming 1564 of working hours per year (source: EUKLEMS 2018, EU28_output_17ii) this is equivalent to an annual earnings 'loss' of 30.6 euro. In other words, if the use of inputs along the GVC had remained unchanged with respect to year 2005, hourly wage of European workers would have been higher by 18 cents in 2014. This effect is not large. As reported in Table 10, the magnitude of the effect estimated for Europe 28 is, however, almost twice higher if we consider the impact of GVC imports coming from developing countries.

The picture changes a bit if we consider only workers from Western Europe and developments in GII therein. The counterfactual calculations for Western European workers result in cumulative hourly wage 'decline' by 0.16 euro which is equivalent to 27.45 euro less of annual earning. This effect is higher when we take into account stronger effect exhibited by GVC imports from developing countries (and measured by $G I I^{D E V}$ ). If the use of inputs along the GVC coming from developing countries had remained unchanged with respect to year 2005, hourly wage of European workers in 2014 would have been higher by 0.7 euro (annual loss of 122 euro). Hence, the effect of global import intensity of production on wages in Western Europe is economically small.

\subsection{Extensions and robustness checks}

We considered numerous robustness checks and extensions of the basic model estimated for workers from 28 European countries. The general result of the negative effect of GII on wages of all European workers is robust to: the way we measure our dependent variable (Table 2A in the online appendix) and changes in the weighting scheme adopted in the regression (Table $3 \mathrm{~A}$ in the online appendix) None of these 


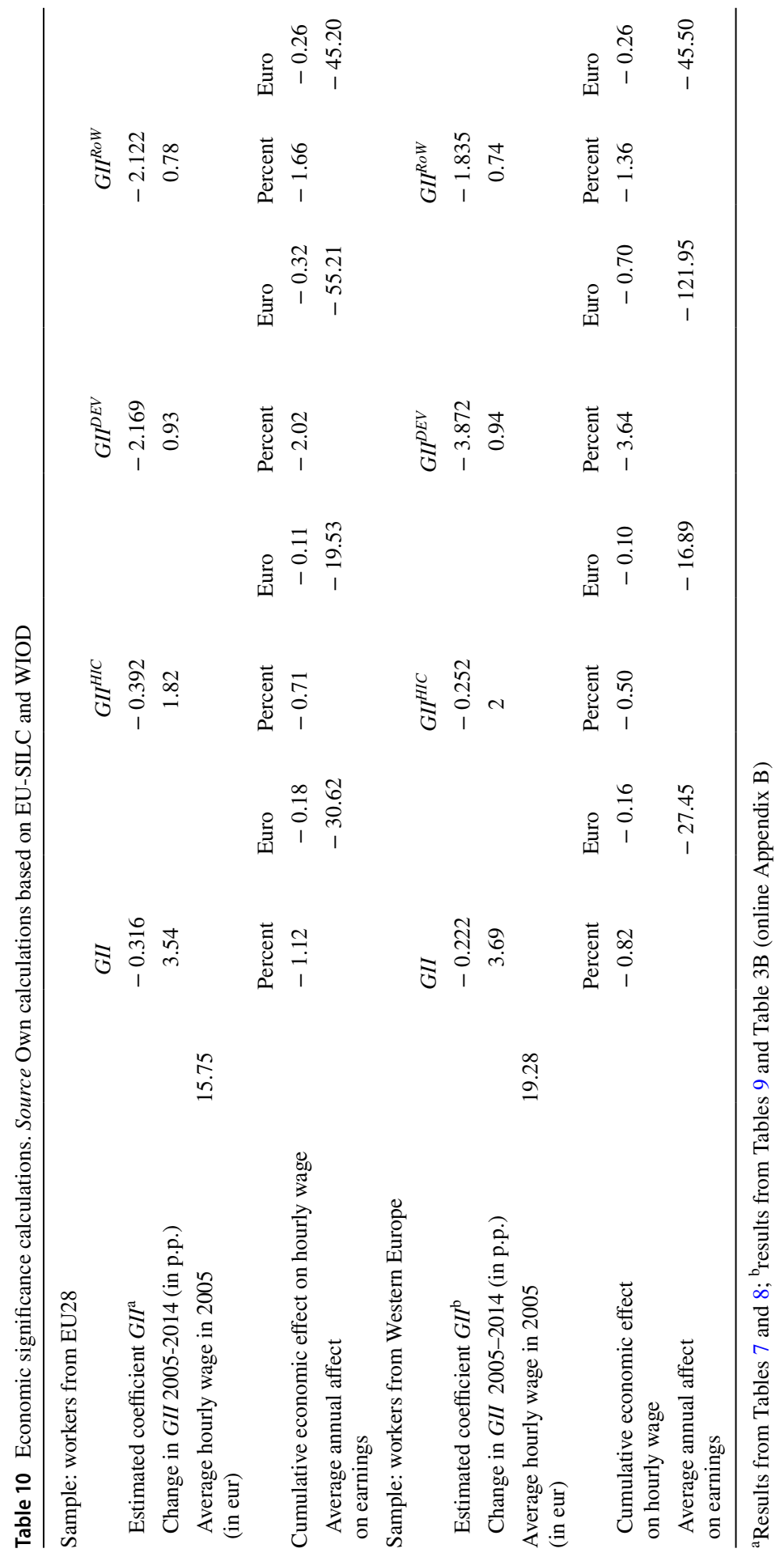


changes alters in a considerable way our main result: negative influence of global import intensity of production on wages of European workers.

Then, even though our model incorporates sector and country specific fixed effects, and thus should capture all the other wage determinants not explicitly included into the model, we considered the extended estimations including additional control variables. Following Geishecker et al. (2010) and Schäfer and Gottschall (2015) we considered differences in labour market institutions and country-specific wage bargaining schemes (Table 4A in online appendix A). We also included variables related to country-level and industry-level trade openness (Table A in online appendix A). Confirming other studies (e.g. Hummels et al. 2014), sectors which are more export oriented (with higher share of export to value added) are characterised by higher wages. In line with the literature on the role of technology in wage determination process (Autor et al. 2003; Acemoglu and Autor 2011; Goos et al. 2014), we also took into account the potential role played by technology and $R \& D$ (we employed industry-level variables on computing, communications and $R \& D$ equipment, expressed either as capital formation or stock-Table 6A in the online appendix). The inclusion of additional country-specific or sector specific variables do not change our main results and interestingly those additional variables are hardly statistical significant. Finally, our results are also not driven by any specific country or industry (we checked it by eliminating, one-by-one, countries or industries from the sample-the results over such limited subsamples showing mean, minimum and maximum coefficients are reported in Table 7A and Table 8A in online appendix A). We also split time of our analysis into pre and post crises; respectively we run regressions for two time periods: 2005-2008 and 2009-2014. As indicated in Table 9A, indeed in the years before the crisis, when the growth of GII was more intensive then afterwards, the effect on wages was two times higher than in the years after 2009 when the slowdown of GII growth was observed (Timmer et al. 2016).

Finally, to check the average industry position in GVCs we introduced in our regression the upstreamness measure (UP) developed by Fally (2011) and Antràs et al. (2012). The index is based on forward linkages and measures an industry's average distance from the final stage of production. ${ }^{42}$ The results of an augmented estimation of the wage model are reported in Table R1: neither UP nor its interaction with $G I I$ is statistically significant. The other explanatory variables (microlevel Mincerian determinants of wages, routinisation of occupation, degree of GVC dependency measured by $G I I$ ) explain up to three quarters of wage variability in our sample.

\footnotetext{
42 Fally (2011) notices that within manufacturing, upstreamness is positively correlated with physical capital intensity and negatively correlated with skill intensity. We have additionally verified the relationship between per capita income (GDPpc) and a country's GVC position. The correlation coefficient between $U P$ and GDPpc in our sample is -0.0166 . This is in line with the previous findings: 'We verify that the bivariate correlation between country upstreamness and log real GDP per capita is not statistically significant.' (Antràs et al. 2012: p.416).
} 


\section{Conclusions}

In this paper we have attempted to contribute to the empirical literature on microeconomic consequences of cross-border production links for European workers. We have addressed several limits of single-country studies on offshoring/production fragmentation and wages. We have used comparable worker-level data from 28 European countries matched with industrial statistics in a methodologically uniform and generally accepted (Mincerian) framework, which should provide a robust set of facts concerning the effects of GVC on wages in Europe. We considered differences in countries level of development or labour market institutions, sectoral specificity, the heterogeneity of foreign inputs according to source countries' characteristics; we took into account country-specific task content of jobs affecting wage levels. The way we measured fragmentation within GVCs (global import intensity of production, GII, computed with newest 2016 World Input-Output Database) allowed us to trace back the involvement of sectors into the global structure of production. This measure, contrary to conventional measures of offshoring, captures imports of goods and services needed in any backward stage of the production of the final product and involves third-country trade. Such a view is more coherent with the key feature of GVC seen as cross-country multistage production network which results in cross-country industrial interdependence. Consequently, we believe it is the broadest European perspective adopted so far to the study of wage response to global production links and our conclusions are not country specific as in many related papers.

Our empirical analysis in the whole sample of 28 European countries shows a negative correlation between the wages of domestic labour and involvement in GVCs (importantly, not only when GVCs are measured by GII but also by other measures). ${ }^{43}$ However, we find significant heterogeneity with respect to subsamples of European countries and with respect to the source of imports along the value chain. The downward pressure on wages concerns mainly workers in Western Europe and is driven by production links with developing countries.

Our results also confirm that the degree of occupation routinisation is a particularly robust determinant of wages (the more routine the job, the lower the wage), regardless of GVC participation. Additionally, in a model focusing on workers employed in Western European countries, GII is connected with the lower wages of workers doing more routine tasks. Hence, in line with our empirical data, Western European workers with more routine jobs may feel more threatened, especially when they have to compete with cheap labor in developing countries (or with the product of their labour, e.g. intermediate inputs produced by routine workers in developing countries), while their counterparts in Central and Eastern Europe may benefit from involvement in GVCs, thanks to greater demand for their labour (owing to the shift

\footnotetext{
43 This is in line with the literature, as the negative correlation between GVC (offshoring) and wages of domestic workers (or some types of workers, i.e. low skilled and/or performing routine tasks) has been shown in previous studies: among others, Amiti and Davis (2011), Baumgarten et al. (2013), Geishecker and Görg (2013), Parteka and Wolszczak-Derlacz (2019), Ebenstein et al. (2014).
} 
of more routine tasks to low-wage countries). Still, this negative wage effect of GII is rather modest and not strong in economic terms.

On the theoretical plane the relationship between wages and GVC involvement is far from straightforward, with insights from various models. The empirical results should be thus interpreted taking into account the intertwined relationship between $G I I$, the level of surpluses, productivity, and wages in industries. Our general results (the negative correlation between GVC and wages) have at least a threefold explanation. One interpretation highlights the pressure on domestic workers to accept lower wages in fear of job displacement; the recent paper of Jeon and Kwon (2019), for instance, develops a theoretical model to show that the threat of offshoring can impact on wages even when there is no actual offshoring. The first interpretation can also be seen as a situation in which the fear of displacement offsets the potential productivity gains from involvement in GVC. Another explanation could be that country-industries with low surpluses, hence low wages, and that share it under bargaining, tend to use more GII in order to increase their surplus. Finally, our results might represent the effect of reallocation of labour between firms/sectors of differing productivity as in equilibrium model by Egger et al. (2015) in which offshoring, unlike international trade in final goods, may reallocate production workers from high- to low-productivity firms. The mechanism is quite simple: falling trade costs, starting from an excessively high level, cause international production fragmentation among the more productive firms, which frees some domestic labour and drives down wages.

An interesting extension of our work could be to separate, for each European downstream country, the parts of GVCs that fall into upstream European countries in the sample. For those GVCs, one could then relate upstream GVCs to downstream wages but also downstream wages to upstream wages in a separate Mincer regression. $^{44}$

Open Access This article is licensed under a Creative Commons Attribution 4.0 International License, which permits use, sharing, adaptation, distribution and reproduction in any medium or format, as long as you give appropriate credit to the original author(s) and the source, provide a link to the Creative Commons licence, and indicate if changes were made. The images or other third party material in this article are included in the article's Creative Commons licence, unless indicated otherwise in a credit line to the material. If material is not included in the article's Creative Commons licence and your intended use is not permitted by statutory regulation or exceeds the permitted use, you will need to obtain permission directly from the copyright holder. To view a copy of this licence, visit http://creativecommons.org/licen ses/by/4.0\%.

\section{References}

Abraham, F., \& Konings, J. (1999). Does the opening of Central and Eastern Europe threaten employment in the west? World Economy, 22(4), 585-601.

44 We thank the anonymous Referee for this suggestion. 
Acemoglu, D., \& Autor, D. H. (2011). Skills, tasks and technologies: Implications for employment and earnings. In O. Ashenfelter \& D. Card (Eds.), Handbook of labor economics (Vol. 4, pp. 10431171). Amsterdam: Elsevier/North-Holland.

Amador, J., \& Cabral., S. (2015). Global value chains, labour markets and productivity. In J. Amador \& F. di Mauro (Eds.), The age of global value chains, Maps and policy issues (pp. 107-120). London: CEPR Press.

Amiti, M., \& Davis, D. R. (2011). Trade, firms, and wages: Theory and evidence. The Review of Economic Studies, 79(1), 1-36.

Antràs, P., Chor, D., Fally, T., \& Hillberry, R. (2012). Measuring the upstreamness of production and trade flows. American Economic Review, 102(3), 412-416.

Antràs, P., \& Chor, D. (2013). Organizing the global value chain. Econometrica, 81(6), 2127-2204.

Arias, O. S., Sánchez-Páramo, C., Dávalos, M. E., Santos, I., Tiongson, E. R., Gruen, C., et al. (2014). Back to work: Growing with jobs in Eastern Europe and Central Asia, Europe and Central Asia reports. Washington, DC.: The World Bank.

Autor, D. H., Levy, F., \& Murnane, R. J. (2003). The skill content of recent technological change: An empirical exploration. The Quarterly Journal of Economics, 118(4), 1279-1333.

Autor, D. H., \& Handel, M. J. (2013). Putting tasks to the test: Human capital, job tasks, and wages. Journal of Labor Economics, 31(S1), S59-S96.

Autor, D.H. (2014). Polanyi's paradox and the shape of employment growth. NBER Working Paper No. 20485. Cambridge, MA: National Bureau of Economic Research.

Autor, D. H., Dorn, D., \& Hanson, G. H. (2013). The China Syndrome: Local labor market effects of import competition in the United States. American Economic Review, 103(6), 2121-2168.

Autor, D. H., Dorn, D., Hanson, G. H., \& Song, J. (2014). Trade Adjustment: Worker-level evidence. The Quarterly Journal of Economics, 129(4), 1799-1860.

Baldwin, J., \& Yan, B. (2014). Global value chains and the productivity of Canadian manufacturing firms. Economic Analysis (EA) Research Paper Series 2014090e. Statistics Canada, Analytical Studies Branch.

Baldwin, R., \& Robert-Nicoud, F. (2014). Trade-in-goods and trade-in-tasks: An integrating framework. Journal of International Economics, 92(1), 51-62.

Baldwin, R., \& Lopez-Gonzalez, J. (2015). Supply-chain trade: A portrait of global patterns and several testable hypotheses. The World Economy, 38(11), 1682-1721.

Baumgarten, D. (2015). Offshoring, the nature of tasks, and occupational stability: Empirical evidence for Germany. The World Economy, 38(3), 479-508.

Baumgarten, D., Geishecker, I., \& Görg, H. (2013). Offshoring, tasks and the skill-wage pattern. European Economic Review., 61, 132-152.

Becker, S. O., Ekholm, K., \& Muendler, M. A. (2013). Offshoring and the onshore composition of tasks and skills. Journal of International Economics, 90(1), 91-106.

Becker, S. O., \& Muendler, M. A. (2015). Trade and tasks: An exploration over three decades in Germany. Economic Policy, 30(84), 589-641.

Blinder, A. S. (2006). Offshoring: The next industrial revolution? Foreign Affairs, 85(2), 113-128.

Blinder, A. S., \& Krueger, A. B. (2013). Alternative measures of offshorability: A survey approach. Journal of Labor Economics, 31(S1), S97-S128.

Costinot, A., Vogel, J., \& Wang, S. (2012). Global supply chains and wage inequality. American Economic Review, 102(3), 396-401.

Costinot, A., Vogel, J., \& Wang, S. (2013). An elementary theory of global supply chains. Review of Economic studies, 80(1), 109-144.

Dauth, W., Findeisen, S., \& Suedekum, J. (2014). The rise of the East and the Far East: German labor markets and trade integration. Journal of the European Economic Association, 12(6), 1643-1675.

De Arcangelis, G., \& Mariani, R. D. (2019). Multi-country tasks measures: Beyond US-based data and a focus on migration. Working Papers Series Dipartimento Di Scienze Sociali ed Economiche No. 5/19. Rome, La Sapienza.

Ebenstein, A., Harrison, A., McMillan, M., \& Phillips, S. (2014). Estimating the impact of trade and offshoring on American workers using the current population surveys. Review of Economics and Statistics, 96(4), 581-595.

EC (2016). Methodological guidelines and description of EU-SILC target variables, 2015 operation (Version June 2016). 
Egger, H., \& Egger, P. (2002). How international outsourcing drives up Eastern European wages. Weltwirtschaftliches Archiv/Review of World Economics, 138(1), 83-96.

Egger, H., Kreickemeier, U., \& Wrona, J. (2015). Offshoring domestic jobs. Journal of International Economics, 97(1), 112-125.

Engel M., Schaffner S. (2012). How to use the EU-SILC panel to analyse monthly and hourly wages. Ruhr Economic Paper 390.

Fally, T. (2011). On the fragmentation of production in the US. University of Colorado-Boulder, mimeo.

Feenstra, R. C. (2010). Offshoring in the global economy: Microeconomic structures and macroeconomic implications. Cambridge: MIT Press.

Feenstra, R. C. (2017). Statistics to Measure Offshoring and its Impact. NBER Working Paper, 23067. Retrieved from https://www.nber.org/papers/w23067.

Feenstra, R. C., \& Hanson, G. H. (1999). The impact of outsourcing and high-technology capital on wages: Estimates for the United States, 1979-1990. The Quarterly Journal of Economics, 114(3), 907-940.

Feenstra, R. C., \& Sasahara, A. (2018). The 'China shock', exports and US employment: A global inputoutput analysis. Review of International Economics, 26(5), 1053-1083.

Franssen, L. (2019). Global value chains and relative labour demand: A geometric synthesis of neoclassical trade models. Journal of Economic Surveys, 33(4), 1232-1256.

Geishecker, I. (2006). Does outsourcing to Central and Eastern Europe really threaten manual workers' jobs in Germany? World Economy, 29(5), 559-583.

Geishecker, I., \& Görg, H. (2013). Services offshoring and wages: Evidence from micro data. Oxford Economic Papers, 65(1), 124-146.

Geishecker, I., Görg, H., \& Munch, J. R. (2010). Do labour market institutions matter? Micro-level wage effects of international outsourcing in three European countries. Review of World Economics, 146(1), 179-198.

Goos, M., Manning, A., \& Salomons, A. (2014). Explaining job polarization: Routine-biased technological change and offshoring. American Economic Review, 104(8), 2509-2526.

Grossman, G. M., \& Rossi-Hansberg, E. (2008). Trading tasks: A simple theory of offshoring. The American Economic Review, 98(5), 1978-1997.

Grossman, G. M., \& Rossi-Hansberg, E. (2012). Task trade between similar countries. Econometrica, $80(2)$, 593-629.

Hardy, W., Keister, R., \& Lewandowski, P. (2018). Educational upgrading, structural change and the task composition of jobs in Europe. Economics of Transition, 26(2), 201-231.

Hummels, D., Ishii, J., \& Yi, K. M. (2001). The nature and growth of vertical specialization in world trade. Journal of International Economics, 54(1), 75-96.

Hummels, D., Jørgensen, R., Munch, J., \& Xiang, C. (2014). The wage effects of offshoring: Evidence from Danish matched worker-firm data. The American Economic Review, 104(6), 1597-1629.

Hummels, D., Munch, J. R., \& Xiang, C. (2018). Offshoring and labor markets. Journal of Economic Literature, 56(3), 981-1028.

ILO (2012). International standard classification of occupations: ISCO-08 structure, group definitions and correspondence tables. Geneva: International Labour Office.

Jeon, Y., \& Kwon, C. W. (2019). Offshoring, the threat effect, and wage inequality. International Journal of Economic Theory. https://doi.org/10.1002/ijet.12221.

Johnson, R. C., \& Noguera, G. (2012). Accounting for intermediates: Production sharing and trade in value added. Journal of International Economics., 86(2), 224-236.

Johnson, R. C., \& Noguera, G. (2017). A portrait of trade in value-added over four decades. Review of Economics and Statistics, 99(5), 896-911.

Kohler, W. (2004). International outsourcing and factor prices with multistage production. The Economic Journal, 114(494), C166-C185.

Koopman, R., Wang, Z., \& Wei, S. J. (2014). Tracing value-added and double counting in gross exports. The American Economic Review., 104(2), 459-494.

Lewandowski, P., Keister, R., Hardy, W., \& Górka S. (2017). Routine and ageing? The intergenerational divide in the deroutinisation of jobs in Europe. IBS Working Paper 01/2017.

Lewandowski P., Park A., Hardy W., \& Du Y. (2019). Technology, skills, and globalization: Explaining international differences in routine and nonroutine work using survey data. IZA Discussion Paper No.12339 https://ftp.iza.org/dp12339.pdf. 
Los, B., Timmer, M. P., \& de Vries, G. J. (2015a). How global are global value chains? A new approach to measure international fragmentation. Journal of Regional Science, 55(1), 66-92.

Los, B., Timmer, M. P., \& de Vries, G. J. (2015). How important are exports for job growth in China? A demand side analysis. Journal of Comparative Economics, 43(1), 19-32.

Markusen, J. R. (1989). Trade in producer services and in other specialized intermediate inputs. The American Economic Review, 79, 85-95.

Parteka, A., \& Wolszczak-Derlacz, J. (2015). Integrated industries—diversified earnings: The (missing) impact of offshoring on wages and wage convergence in the EU27. Journal of Economic Inequality, 13(3), 325-350.

Parteka, A., \& Wolszczak-Derlacz, J. (2019). Global value chains and wages: Multi-country evidence from linked worker-industry data. Open Economies Review, 30(3), 505-539.

Polgár, É. K., \& Wörz, J. (2010). No risk and some fun? Trade and wages in the enlarged European Union. Empirica, 37(2), 127-163.

Timmer, M. P., Dietzenbacher, E., Los, B., Stehrer, R., \& De Vries, G. J. (2015). An illustrated user guide to the world input-output database: The case of global automotive production. Review of International Economics, 23(3), 575-605.

Timmer, M. P., Los, B., Stehrer, R., \& De Vries, G.J. (2016). An anatomy of the global trade slowdown based on the WIOD 2016 release. GGDC Research memorandum Nr. 162, December 2016, Groningen Growth and Development Centre.

Schäfer, A., \& Gottschall, K. (2015). From wage regulation to wage gap: How wage-setting institutions and structures shape the gender wage gap across three industries in 24 European countries and Germany. Cambridge Journal of Economics, 39(2), 467-496.

Shen, L., \& Silva, P. (2018). Value-added exports and US local labor markets: Does China really matter? European Economic Review, 101, 479-504.

Spitz-Oener, A. (2006). Technical change, job tasks, and rising educational demands: Looking outside the wage structure. Journal of Labor Economics, 24(2), 235-270.

Staiger, D., \& Stock, J. H. (1997). Instrumental variables regression with weak instruments. Econometrica, 65(3), 557-586.

Szymczak S., Parteka A., \& Wolszczak-Derlacz J. (2019). Position in global value chains: the impact on wages in Central and Eastern European Countries. GUT FME Working Papers Series A, No 1/2019(53). [ link to the code in R to compute GII].

Visser, J. (2016). ICTWSS Data base. Version 5.1. Amsterdam: Amsterdam Institute for Advanced Labour Studies (AIAS), University of Amsterdam.

Wang, Z., Wei, S.-J., \& Zhu, K. (2013). Quantifying international production sharing at the bilateral and sector levels. NBER working paper 19677. Cambridge, MA

Wolszczak-Derlacz, J., \& Parteka, A. (2018). The effects of offshoring to low-wage countries on domestic wages. A worldwide industrial analysis. Empirica. Journal of European Economics., 45, 129-163.

Publisher's Note Springer Nature remains neutral with regard to jurisdictional claims in published maps and institutional affiliations.

\section{Affiliations}

\section{Aleksandra Parteka ${ }^{1}\left[\right.$. Joanna Wolszczak-Derlacz ${ }^{1}$ (])}

Joanna Wolszczak-Derlacz

jwo@zie.pg.gda.pl

1 Faculty of Management and Economics, Gdansk University of Technology, Narutowicza 11/12, 80-233 Gdańsk, Poland 